Article

\title{
Interdisciplinary Analysis of Social Acceptance Regarding Electric Vehicles with a Focus on Charging Infrastructure and Driving Range in Germany ${ }^{+}$
}

\author{
Amelie Burkert *(D), Heiko Fechtner and Benedikt Schmuelling (i) \\ School of Electrical, Information and Media Engineering, University of Wuppertal, Rainer-Gruenter-Str. 21, \\ 42119 Wuppertal, Germany; fechtner@uni-wuppertal.de (H.F.); schmuelling@uni-wuppertal.de (B.S.) \\ * Correspondence: burkert@uni-wuppertal.de \\ + This paper is an extended version of our paper published in the 16th IEEE Vehicle Power and Propulsion \\ Conference, 14-17 October 2019, Hanoi, Vietnam.
}

check for updates

Citation: Burkert, A.; Fechtner, H.; Schmuelling, B. Interdisciplinary Analysis of Social Acceptance Regarding Electric Vehicles with a Focus on Charging Infrastructure and Driving Range in Germany . World Electr. Veh. J. 2021, 12, 25. https:// doi.org/10.3390/wevj12010025

Received: 16 November 2020 Accepted: 7 February 2021 Published: 11 February 2021

Publisher's Note: MDPI stays neutral with regard to jurisdictional claims in published maps and institutional affiliations.

Copyright: (c) 2021 by the authors. Licensee MDPI, Basel, Switzerland. This article is an open access article distributed under the terms and conditions of the Creative Commons Attribution (CC BY) license (https:// creativecommons.org/licenses/by/ $4.0 /)$.
Abstract: A variety of measures are currently being taken on both the national and international levels in order to mitigate the negative effects of climate change. The promotion of electric mobility is one such measure for the transport sector. As a key component in a more environmentally-friendly, resource-saving, and efficient transport sector, electric mobility promises to create better sustainability. Several challenges still need to be met to exploit its full potential. This requires adapting the car technology, the value chain of vehicles, loads on the electricity network, the power generation for the drive, traffic, and charging infrastructure. The challenges to this endeavor are not only technical in nature, but they also include social acceptance, concerns, and economic, as well as ecological, aspects. This paper seeks to discuss and elucidate these problems, giving special focus to the issues of driving range, phenomenon of range anxiety, charging time, and complexity of the charging infrastructure in Germany. Finally, the development of social acceptance in Germany from 2011 to 2020 is investigated.

Keywords: charging infrastructure; wireless power transfer; conductive charging; electric vehicles; range anxiety; social acceptance

\section{Introduction}

Climate change is one of greatest challenges with which humanity is currently confronted. High concentrations of carbon dioxide $\left(\mathrm{CO}_{2}\right)$ in Earth's atmosphere is one of the causes of this phenomenon. The resulting greenhouse effect has been linked to global warming and to natural catastrophes (e.g., desertification, droughts, fire, melting glaciers, coastal flooding) [1].

As the second highest-ranking culprit in GHG emissions after the energy sector, the transport sector produces immense amounts of $\mathrm{CO}_{2}$ [2]. Figure 1 offers a breakdown into $\mathrm{CO}_{2}$ emissions in general sectors and the transport sector in detail [3]. Overall, the transport sector accounts for $24 \%$ of the total $\mathrm{CO}_{2}$ emission. Of this, passenger transport produces, on its own, $60.6 \%$ and is, therefore, an important starting point for fundamental changes. Electric vehicles need to usurp the position held by conventional vehicles to greater and greater degrees to enable a more environmentally friendly and resource-saving transport sector. Such a change to the sector poses difficult and new burdens on the automotive industry. It not only requires new drive and charging technologies to be developed, but also a completely new charging infrastructure, which is also discussed to some extent in [4]. 


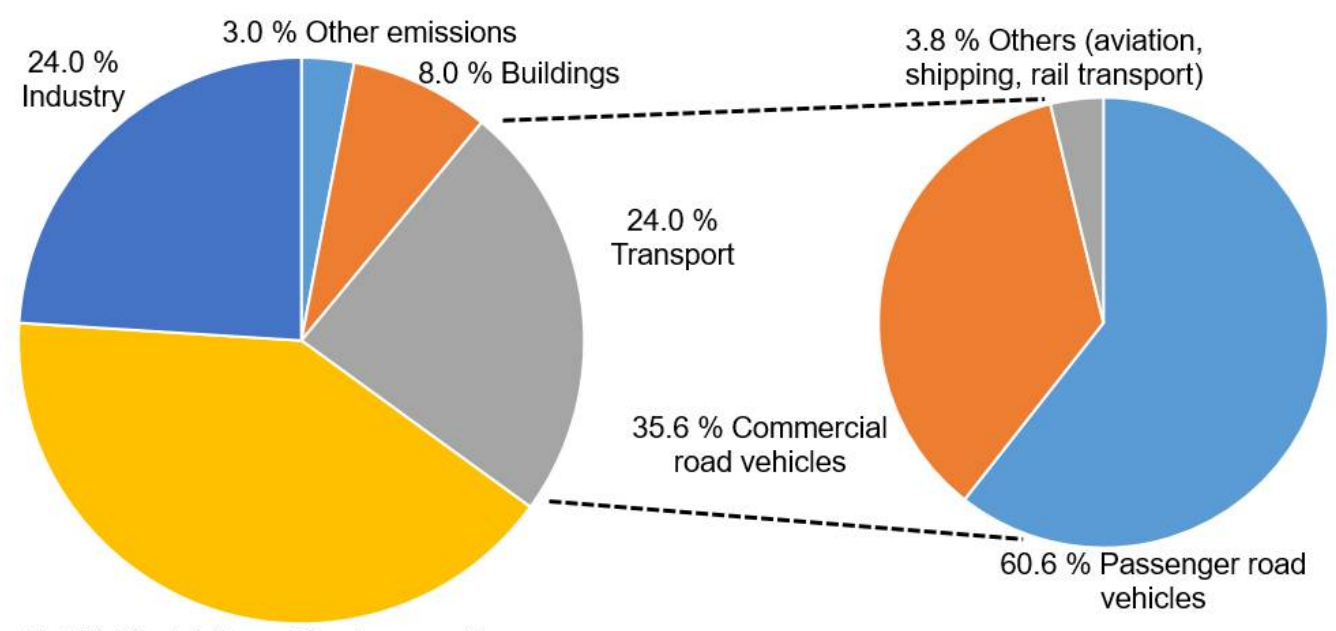

$41.0 \%$ Electricity and heat generation

Figure 1. Breakdown of $\mathrm{CO}_{2}$ emission by general sectors (left) and within transport sector (right) in 2017 [5].

\subsection{Greenhouse Gas in Germany's Transport Sector}

Power supply from renewable energy is to be preferred to truly be able to call electromobility sustainable. However, this lofty goal is not yet within reach. In 2015, energy in the transport sector was mostly obtained from non-renewable resources (e.g., $94 \%$ fossil fuel, $2 \%$ gas) and only $4 \%$ from renewable resources [5], and this ratio has not yet changed significantly to date. The number of hybrid and purely electric vehicles only represent $2 \%$ of the total number of registered vehicles in Germany [6]. It must also be noted that the production of electric vehicles (EVs) is very $\mathrm{CO}_{2}$ intensive, with the environmental impact by $\mathrm{CO}_{2}$ emissions in the production of electric vehicles being two-thirds higher than for conventional vehicles due to the way in which the batteries are produced [7]. After their production, electric vehicles have the potential of causing nearly zero emissions, provided that the power is based on renewable energy. Be that as it may, without renewable energy resources, life cycle analysis shows that emissions of EVs are comparable with conventional vehicles.

For instance, Figure 2 shows the impact of various energy sources on carbon emissions. A purely electric Nissan Leaf with two different energy sources (German electricity mix 2015 and 2019, German renewable power of 2019) is compared with two conventional Nissan vehicles (Nissan Juke and Nissan Micra) [8]. The vehicles that are presented in Figure 2 have been chosen for an easy comparison of different vehicles from one manufacturer and to consider the Nissan Leaf, which is one of the best-selling vehicles worldwide [9]. The vehicles are comparable in their size and configuration. The calculations are based on the worldwide harmonized light-duty vehicles test procedure (WLTP) and [10]. The worst-case scenario was considered, in which it is assumed that Nissan Leaf production causes a total of $10 \mathrm{t} \mathrm{CO}$ (as compared to a conventional Nissan vehicle, which produces $6 \mathrm{t}$ ). Battery production accounts for a large part of total $\mathrm{CO}_{2}$ and it varies depending on the capacity of the battery installed.

If supplied by the German electricity mix of 2019, the climate balance of Nissan Leaf is better after approximately 65,000 $\mathrm{km}$ when compared to Nissan Juke and after approximately $165,000 \mathrm{~km}$ as compared to Nissan Micra. With an annual mileage of less than 15,000 km [11], the purchase of a Nissan Leaf does not provide any significant advantages before a vehicle age of 10 years. The climate balance would only be better after $>11$ years in comparison to conventional Nissan Micra (see Table 1). On the other hand, the purchase of Nissan Leaf would already be worthwhile at an annual mileage of $10,000 \mathrm{~km}$ as compared to the Nissan Juke. Accordingly, a higher mileage per year means a better carbon footprint. The difference becomes even more pronounced when a Nissan Leaf is powered by renewable energy. After only $25,000 \mathrm{~km}$, its climate balance is better 
than that of a conventional Nissan Juke and after 40,000 km better than that of a Nissan Micra. Table 2 shows the annual average mileage of the population in Germany and it highlights the percentage of the population for whom the purchase of a Nissan Leaf would be beneficial compared to a Nissan Juke or Nissan Micra. For example, if an owner of an EV drives 20,000 km per year, their climate balance would be better after only 1.7 (Nissan Juke) to 2.7 (Nissan Micra) years, while taking that it is charged with renewable power into account (see Table 1).

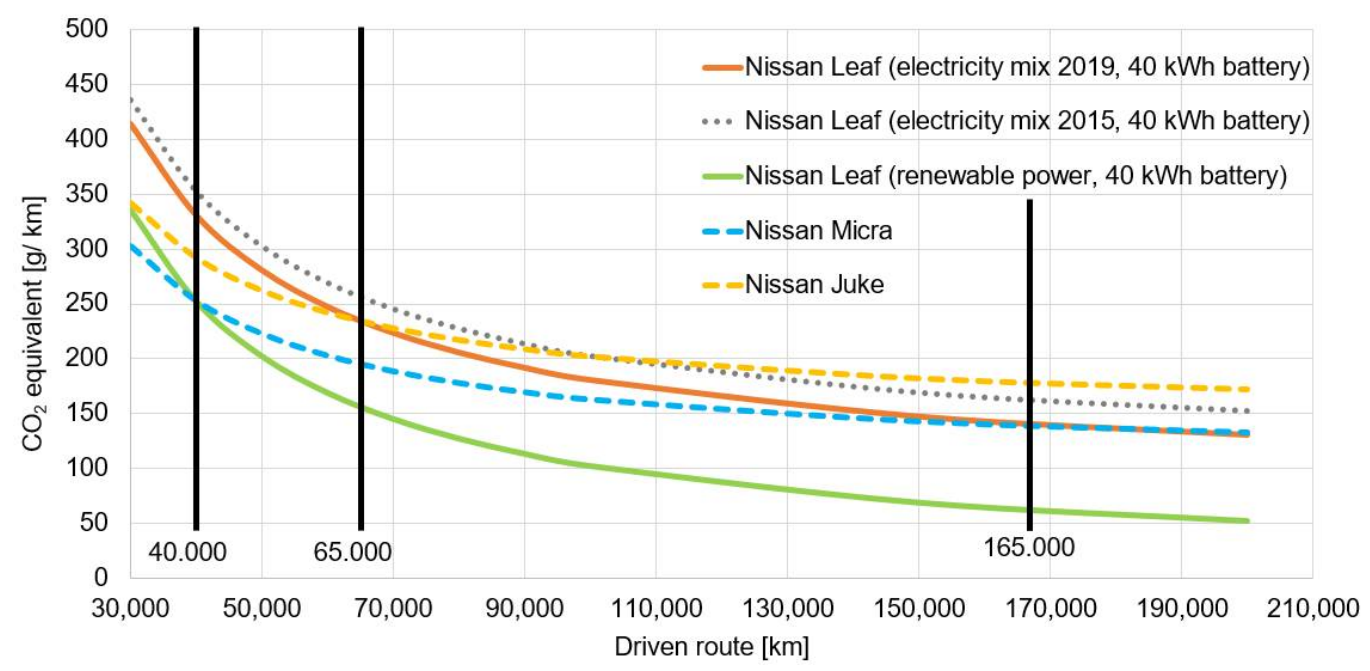

Figure 2. Carbon footprint of different Nissan vehicle types $[8,12]$.

Table 1. Improvement of Nissan Leaf's ecological balance over conventional Nissan vehicles in years [a] (depending on power supply and annual mileage [km]).

\begin{tabular}{ccccc}
\hline \multirow{2}{*}{$\begin{array}{c}\text { Annual Mileage } \\
{[\mathbf{k m}]}\end{array}$} & \multicolumn{2}{c}{ Electricity Mix of 2019 } & \multicolumn{2}{c}{ Renewable Power } \\
\cline { 2 - 5 } & $\begin{array}{c}\text { Nissan Micra } \\
{[\mathbf{a}]}\end{array}$ & Nissan Juke [a] & $\begin{array}{c}\text { Nissan Micra } \\
{[\mathbf{a}]}\end{array}$ & Nissan Juke [a] \\
\hline $5001-10,000$ & $16.5-33$ & $6.5-13$ & $4-8$ & $2.5-5$ \\
\hline $10,001-15,000$ & $11-16.5$ & $4.3-6.5$ & $2.7-4$ & $1.7-2.5$ \\
\hline $15,001-20,000$ & $8.3-11$ & $3.3-4.3$ & $2-2.7$ & $1.3-1.7$ \\
\hline
\end{tabular}

Table 2. Percentage of the population driving various annual mileages (2019). The data regarding annual mileage is based on data published by the Federal Motor Transport Authority [11].

\begin{tabular}{cc}
\hline Annual Mileage $[\mathbf{k m}]$ & Percentage of Population [\%] \\
\hline $0-5000$ & 12.97 \\
\hline $5001-10,000$ & 29.06 \\
\hline $10,001-15,000$ & 29.53 \\
\hline $15,001-20,000$ & 15.06 \\
\hline more than 20,000 & 13.37 \\
\hline
\end{tabular}

\subsection{EU Policies Regarding $\mathrm{CO}_{2}$ Emissions}

An examination of $\mathrm{CO}_{2}$ emissions of newly registered vehicles over the last few years reveals that $\mathrm{CO}_{2}$ emissions have decreased by about 30\% between 1998 and 2017 (as shown in Figure 3) only to have increased again by 20\% within two years (in 2018 and 2019) [13]. This development can be explained by the significant higher share of newly registered vehicles in vehicle segments, like luxury vehicles, SUVs, ATVs, sport vehicles, utility 
vehicles, and recreational vehicles (when compared to 2018). Figure 4 shows the difference of the new vehicle registration from 2019 to 2018 for each vehicle class (in white). A significant increase can be noted in the compact class $(+1.5 \%)$, sport utility vehicles (SUVs) $(+2.9 \%)$, and all-terrain vehicles (ATVs) $(+1.4 \%)$ [14]. Overall, almost $5 \%$ more vehicles (approx. 621,190 vehicles) were registered in 2019 as compared to the previous year [14]. Luxury vehicles, SUVs, ATVs, sport vehicles, utility vehicles, and recreational vehicles produce a higher amount of $\mathrm{CO}_{2}$, which leads to an overall increase of the average $\mathrm{CO}_{2}$ emission of all newly registered vehicles in Germany [6]. More than 13.2 million vehicles of the luxury and leisure classes were registered in Germany in 2019 (2018: 12.39 million, 2017: 11.64 million). This means that approximately $50 \%$ of new vehicle registrations were for luxury and leisure vehicles from 2017 to 2019 [14]. Figure 4 depicts the percentage distribution of vehicle classes. This distribution can also serve to explain the enormous increase in the average $\mathrm{CO}_{2}$ emissions $\left(158 \mathrm{~g} \mathrm{CO}_{2} / \mathrm{km}\right)$ in 2019 (Figure 3).

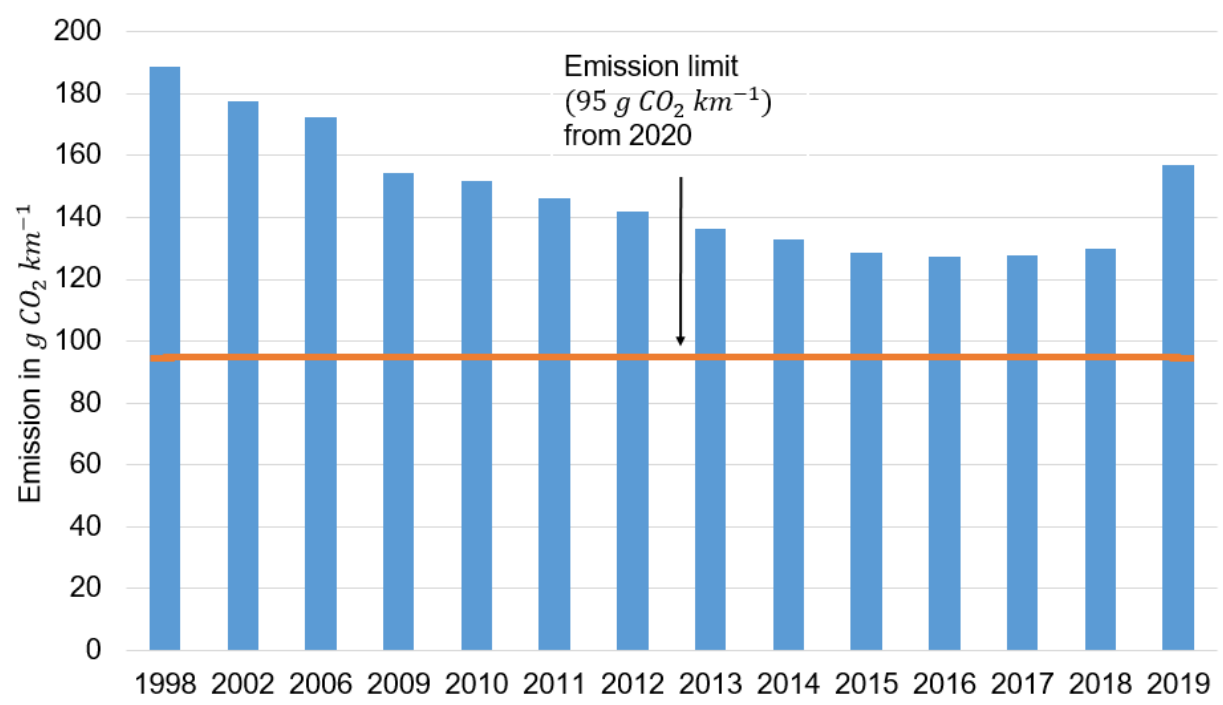

Figure 3. Average $\mathrm{g} \mathrm{CO}_{2} / \mathrm{km}$ from newly registered vehicles in Germany (from 1998 to 2019) [14,15].

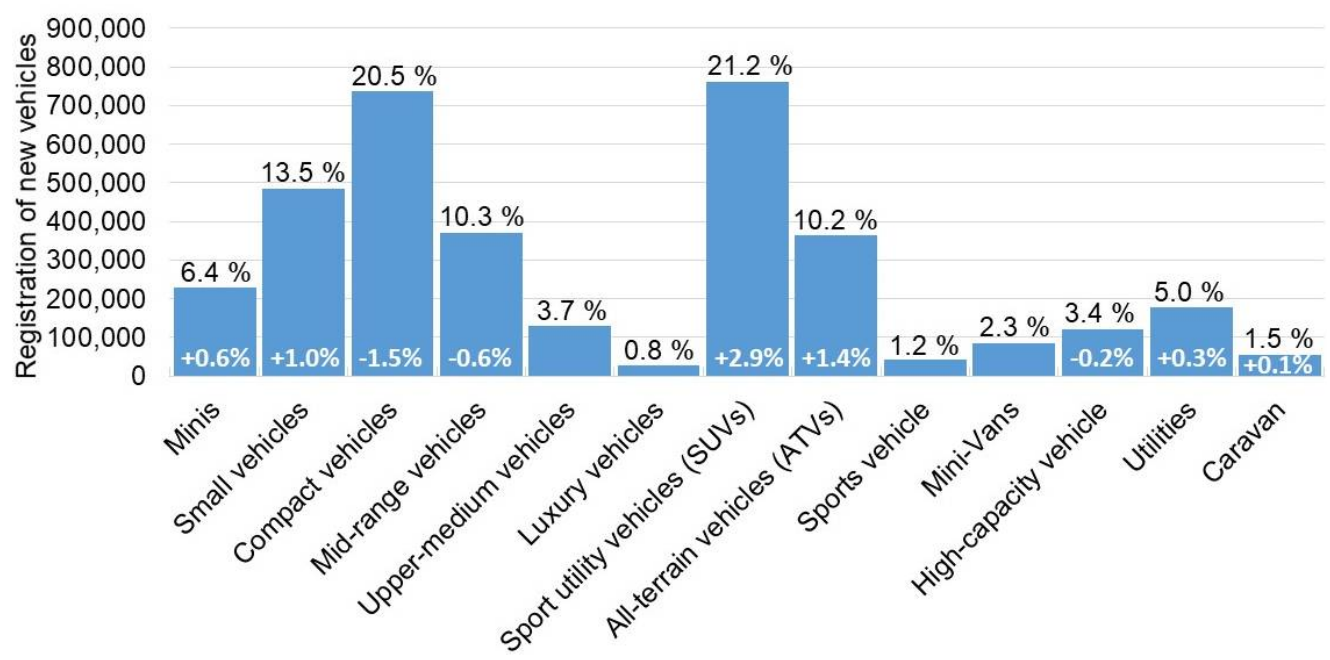

Figure 4. Newly registered vehicles sorted by vehicle class in 2019. The data is based on data obtained from the website of the German Federal Motor Transport Authority [14]. In white: the difference to the year 2018.

Because of this development, the European Union felt itself compelled to act and has since introduced a law to try and counteract this trend. With an aim to reduce greenhouse gas emissions, the European Union Regulation 2019/631 was published in April 2019 [15] 
and states that, as of 1 January 2020, a target value of $95 \mathrm{~g} \mathrm{CO}_{2} / \mathrm{km}$ may not exceed $95 \%$ of newly registered passenger cars. This target value refers to the entire vehicle fleet of a manufacturer. From 1 January 2021, 100\% of newly registered vehicles must not exceed the limit value of $95 \mathrm{~g} \mathrm{CO}_{2} / \mathrm{km}$. The restriction that is introduced in 2020 must be viewed critically, because vehicles with significantly more than $95 \mathrm{~g} \mathrm{CO}_{2} / \mathrm{km}$ can be put on the market as long as the average emissions of the entire fleet are below this value. Figure 3 also shows the guideline value valid from 2020 and it represents the hurdle that must still be overcome in reducing greenhouse gas emissions. The current value of approximately $155 \mathrm{~g} \mathrm{CO}_{2} / \mathrm{km}$ must be reduced by $61 \%$.

\subsection{Applied Methodology and Research Question}

Over the years, several studies have been published on the topic of barriers to electromobility. Studies, such as [16-18], are focused on identifying, categorizing, and weighting these barriers. For this purpose, social-empiric studies were conducted and evaluated in the relevant regions. In particular, the study [16] from 2020 shows that, currently, the issues of range and charging infrastructure still play an important role in social acceptance. Another study [19] is based on the barriers that were identified in other studies for a sensitivity analysis. This methodology is intended to show the extent to which changes or developments in barriers have affected social acceptance over the years. For our work, we took our cues from studies, such as [16-18], with a special focus on a current opinion survey [16]. In particular, we looked at the barriers of range, charging time, and charging infrastructure in Germany.

The charging infrastructure for EVs is often cited as a counterargument for purchasing an EV (see the studies $[16,18,20]$ ). It is for this reason that the focus of this paper is placed on the charging infrastructure, on the one hand, and, on the other hand, on the driving range of EVs in combination with the charging time, as it is argued that the technology is not mature and causes, among other things, the phenomenon of range anxiety. Hence, the main goal of this paper is to analyze current charging technologies for EVs. Additionally, the paper also presents an analysis of the range of current EVs and the driving behavior of potential owners of EVs. The applied interdisciplinary approach includes, among others, a detailed literature review of current research publication, political framework (e.g., funding programs), laws, and standards. In Chapter 4, the outcomes of the analysis are compared with two studies from 2011 and 2020, and focused on social acceptance for EVs. Thus, this paper provides detailed insight into two of the main barriers of social acceptance for EVs and seeks to answer the research question of whether the current measures are sufficient to have a positive effect on social acceptance. In addition, recommendations on how these barriers might be overcome are given in the conclusion.

\subsection{Structure of the Paper}

Section 2 provides an overview of the barriers to electromobility. The topics of energy storage and insecurity in dealing with accidents are only touched upon. Further, the paper presents a detailed exploration of the range problem of electric vehicles. Particular attention is paid to the phenomenon of range anxiety, the development of battery technology, and the importance of charging time. The range is a decision criterion when buying an electric vehicle and it is an important factor in planning the charging infrastructure and it defines the distribution and density of charging spots [21]. In the next part, the topic of charging infrastructure is then taken up. To supply these electric vehicles with (renewable) energy, a corresponding charging infrastructure for the public and private sectors must be developed and set up according to the requirements. Section 2.5.1 will then examine the current status of Germany's charging infrastructure and compare it to that of other countries (e.g., EU, USA, China). This will be followed by a discussion of numerous factors (geographic characteristics, target group, charging technologies, pricing, backend and roaming, authorization process), which influence the planning of the charging infrastructure. The next section will present an analysis of social acceptance of EVs from 2011 to 2020 while using two 
studies that are based on the five barriers (see Figure 5) to highlight how measures taken so far have affected social acceptance and how thematic priorities have shifted. Finally, the conclusion summarizes the main findings and results of this work.
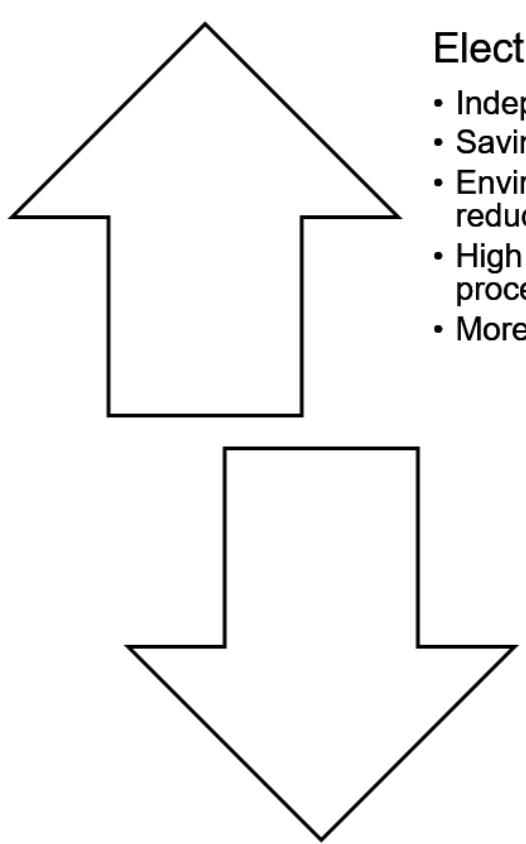

Electric mobility's benefits

- Independence from oil imports

- Saving resources

- Environmentally friendly due to reduced emissions

- High efficiency in well-to-wheel process

- More efficient energy use

\section{Electric mobility's barriers}

- Expensive energy storage

- High acquisition costs

- Insecurity in dealing with accidents

- Limited range

- Long charging time

- Poorly developed charging infrastructure

Figure 5. Electric mobility's benefits and barriers.

\section{Barriers of Social Acceptance}

Establishing a new technology on the automotive market can, at times, be a Herculean task. At the time of writing, there are still various obstacles standing in the way of achieving a broad social acceptance of electric vehicles. Figure 5 shows the most salient of these barriers. These barriers are important to discuss as it is quite logical that electric mobility can only be successfully established as the new form of mobility if all the population's doubts can be dispelled. The individual challenges that have led to the barriers in public perception are explained below. This is followed by a discussion of the development and progress made over the years on the individual issues. Finally, Chapter 3 shows that the measures taken have had a positive effect and the social acceptance of electric vehicles has changed significantly.

\subsection{Energy Storage}

Despite the fact that the price of built-in energy storage systems has been steadily decreasing over the years, electric vehicles today are still up to $40 \%$ more expensive than conventional vehicles [22].

Those energy storage systems consist of many separate lithium-ion battery packs and the price per pack ten years ago was about $\$ 800$. In the meanwhile, the price has fallen by $75 \%$ by 2017 [23], and forecasts for the future look promising; the price per pack will continue to fall as countries are forced to put more electric vehicles on the roads. The higher the demand for electric vehicles, the higher the demand for batteries and the greater the cost of energy storage will decrease [24]. Research in this field works on optimizing various characteristics, such as battery size, the chemical composition of the battery, cell quality, cell size, and format (see Section 2.3), all of which affect the cost of the total battery pack. Figure 6 illustrates the development of battery pack cost over years from 2010 onwards. 


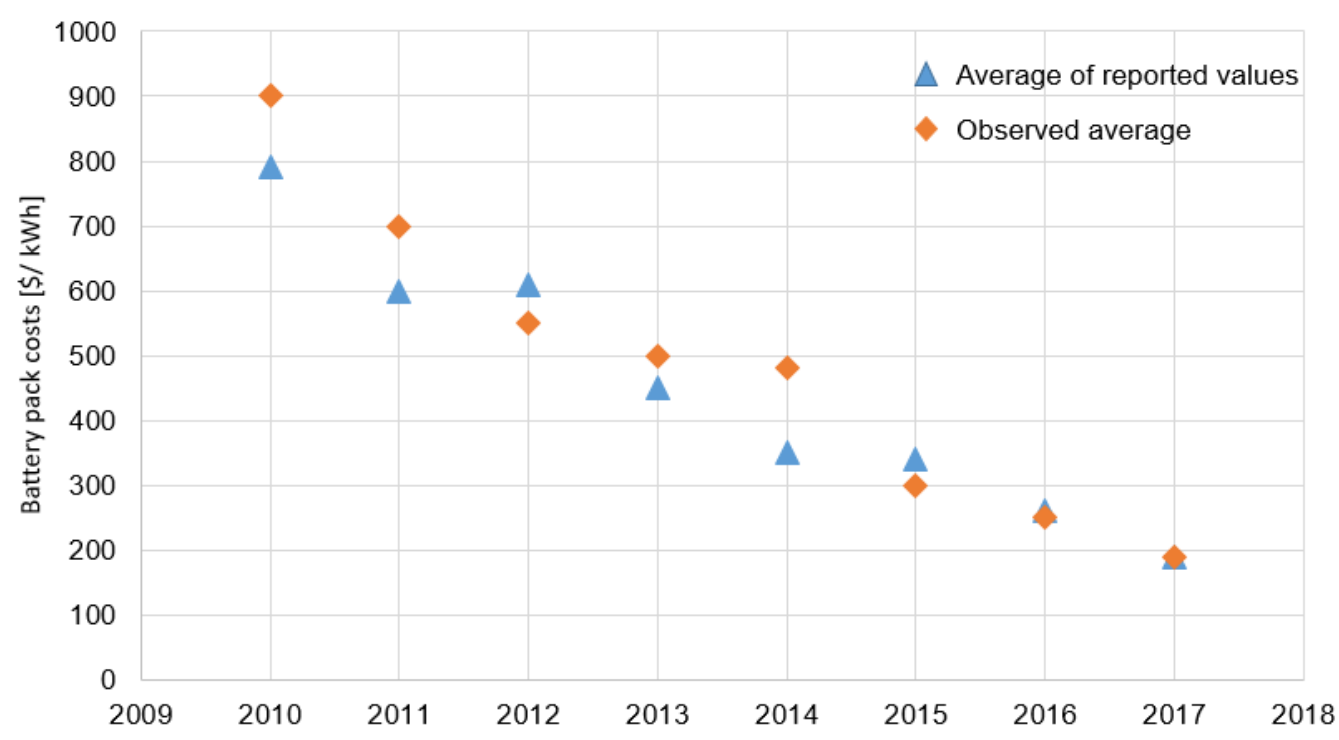

Figure 6. Cost development of lithium-ion battery packs for electric vehicles (from 2009 to 2018) [23]. The reported average is the simple average of statements made by market leaders and what the industry reported (blue triangles). Observed average prices are based on Bloomberg New Energy Finance's industry survey (orange rhombi).

Looking at well-to-wheel analysis, which includes the entire process chain from the provision of drive energy (electricity, petrol, diesel) to the conversion into kinetic energy, it is noticeable that electric vehicles are comparable to conventional vehicles on highways (over $100 \mathrm{~km} / \mathrm{h}$ ). On urban traffic routes (up to $30 \mathrm{~km} / \mathrm{h}$ ) and intercity routes (up to $80 \mathrm{~km} / \mathrm{h}$ ), the consumption and emissions are reduced by more than half [25]. Furthermore, the results that were obtained by [25] also show that electric vehicles are highly efficient when compared to conventional internal combustion vehicles (the average power consumption is $0.47 \mathrm{MJ} / \mathrm{km}$ compared to $2.46 \mathrm{MJ} / \mathrm{km}$ of fuel for conventional vehicles), with the consumption of non-renewable primary energies and generation of greenhouse gas emissions by EVs taking place during the production, transport, conversion, and distribution of electricity (charging device ( $3 \mathrm{~kW}$ to $50 \mathrm{~kW}$ ): $0.26 \mathrm{MJ}$ to $0.28 \mathrm{MJ}$; petrol/diesel: $0.86 \mathrm{MJ}$ ). Nevertheless, an adequate charging infrastructure must be developed to truly make electric vehicles a feasible option for frequent use. Therefore, the diffusion and sustainability of electric vehicles is not based on a further improvement of the vehicle itself (currently this problem is only linked to the costs), but to the development of adequate infrastructures, the efficiency, and use of renewable energy sources in electricity production.

\subsection{Insecurity in Dealing with Accidents}

The energy storage system that is used in EVs presents a new challenge in the event of a car accident [26]. A battery consists of hundreds of individual cells; should one be damaged, a chain reaction of electrical short circuits could follow causing overheating, which, in turn, means that any fire caused by the accident would constantly be reignited, a phenomenon that is known as thermal runaway [27]. Extinguishing such a fire could take hours and requires several thousand liters of water. On top of that, a thermal imaging camera or smoke sensors would need to be used to check whether the fire has been completely extinguished [28]. A fire that is caused by an EV is not necessarily more dangerous by one affecting a conventional vehicle; it must simply be treated differently due to the chemical reactions involved. In particular, care must be taken during the first $24 \mathrm{~h}$ following the fire, as cells could reignite at any time. This additional precaution means that EV wrecks are stored separately [29]. 


\subsection{Driving Range of Current Electric Vehicles}

Shifting from conventional vehicles to electric vehicles faces a series of challenges that must be overcome, such as the purchase costs, charging infrastructure, and charging time, as already stated above. The driving range of current electric vehicles is another often-cited challenge to the shift to electric mobility. This can be underlined, e.g., by [30], in which the authors demonstrate that the driving range of electric vehicles is one of the main barriers. For example, $35 \%$ of the interviewees in Germany name the driving range as an obstacle with regard to buying an electric vehicle [30]. However, the range of today's electric vehicles is much greater when compared to electric vehicles from several years ago. Moreover, the study [31] that was published in 2016 concludes that the daily mileage of American citizens was $50.7 \mathrm{~km}$ (green line in Figure 7). In Germany, the average daily travel distance was $46 \mathrm{~km}$ in 2017 [32] as can be seen in Figure 7 (black line). A further finding of this study [32] is that full-time employees drove, on average, $65 \mathrm{~km}$ daily. The average mileage of weekend trips was $52 \mathrm{~km}$ per day. In addition, the study [32] highlights the differences between rural areas and urban areas. In 2017, Germans living in rural areas drove, on average, $52 \mathrm{~km}$ and people living in urban areas drove an average of $42 \mathrm{~km}$ [32]. These average travel distances cited in [32] are then strongly incongruent with the findings of [30] and the phenomenon of range anxiety considering the driving ranges of modern $\mathrm{EVs}$, and this needs to be further investigated.

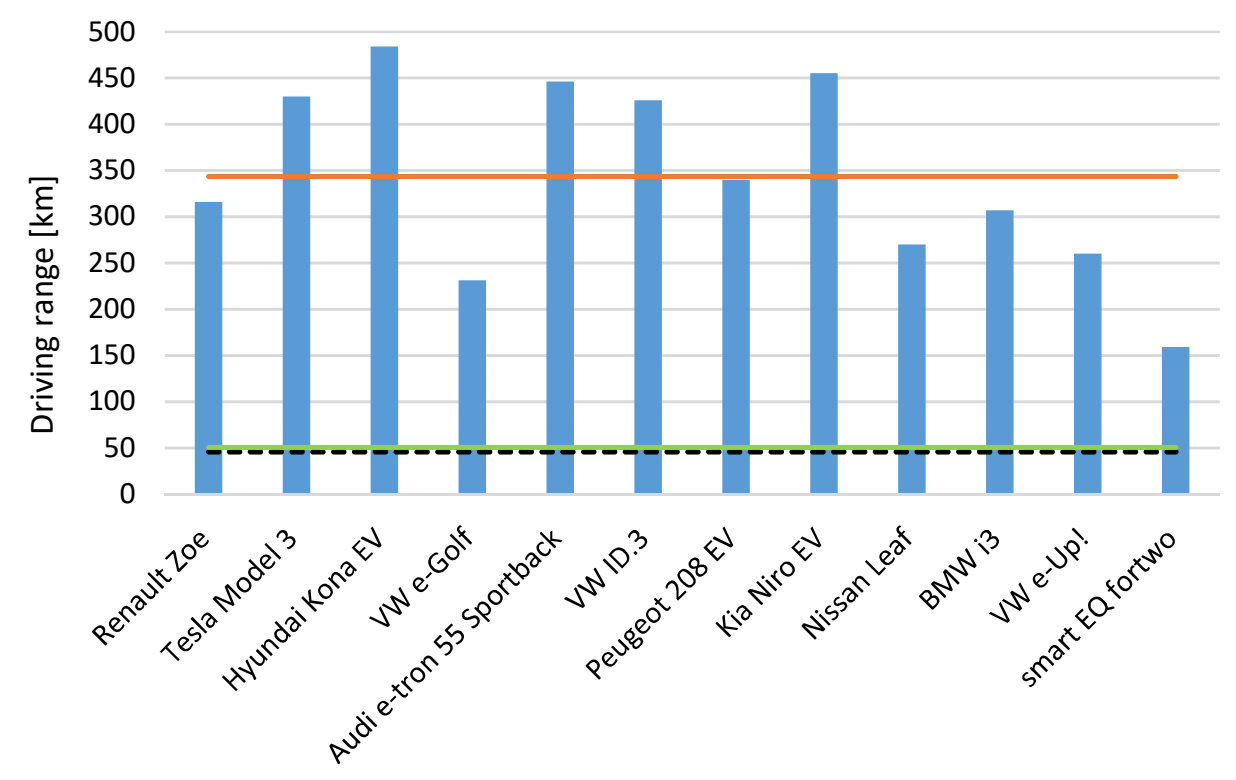

Figure 7. Driving range of current electric vehicles compared with average daily driving range of American (green line) and German (black line) motorists and the average driving range of the analyzed EVs (orange line). The data of the driving range is based on data presented on the websites of the various manufacturers. The average daily driving range for the USA was taken from [31] and for Germany from [32].

The following example illustrates the extension of the driving range of electric vehicles in recent years. In 2014, the majority of small electric vehicles had a driving range below $150 \mathrm{~km}$ [33]. When compared to the data from 2014, the average driving range of the same class of vehicle was $220 \mathrm{~km}$ in 2019 [33]. This corresponds to an increase in driving range of about $46.67 \%$ in five years.

The authors of this paper conducted their own data analysis to provide further evidence regarding this trend. This analysis included data on 12 electric vehicles that are currently available on the market. The vehicle selection was done based on their sales volume in Europe between January to November in 2020, see Table 3. When compared to the sales volume of the EVs (BEV: 338,918; PHEV: 346,112) [34], the total sales volume of all 
new car registrations in the EU was 11.96 million vehicles between January to November in 2020 [35]. In addition, 194,163 EVs and, in total, 2.2 million passenger vehicles with a combustion engine have been registered in Germany in 2020 [36]. Thus, EVs still have a small share of total vehicle registrations in the EU and Germany.

Table 3. Selected vehicles for the analysis of the driving range of modern electric vehicles (EVs) [37].

\begin{tabular}{ccc}
\hline Vehicle Model & Sales Volume & Battery Capacity [kWh] \\
\hline Renault Zoe & 83,356 & 41 \\
\hline Tesla Model 3 & 63,086 & 55 \\
\hline Hyundai Kona EV & 37,202 & 64 \\
\hline VW e-Golf & 31,326 & 35.8 \\
\hline Audio e-tron 55 Sportback & 30,181 & 86.5 \\
quattro & 28,839 & 62 \\
\hline VW ID.3 & 28,137 & 50 \\
\hline Peugeot 208 EV & 27,049 & 64 \\
\hline Kia Niro EV & 26,366 & 40 \\
\hline Nissan Leaf & 20,647 & 42.2 \\
\hline BMW i3 & 18,176 & 36.8 \\
\hline VW e-Up! & 16,226 & 17.6 \\
\hline smart EQ fortwo & &
\end{tabular}

In view of the increasing number of new electric vehicles models in recent years, future publications will consider a greater number of electric vehicles. The range of the selected vehicles is between $159 \mathrm{~km}$ (Smart EQ fortwo) and $484 \mathrm{~km}$ (Hyundai Kona EV) according to WLTP, see Figure 7. The average driving range of the analyzed electric vehicles is $343.67 \mathrm{~km}$ (orange line in Figure 7), which is significantly higher than the driving range of $220 \mathrm{~km}$ that is presented in [33], which depends on the greater battery capacities of modern EVs, see Table 3.

One of the key drivers of this welcome development is the growing energy density of lithium-ion batteries. The battery technology has considerable influence on the range of electric vehicles. On the one hand, more stored energy at the same battery weight makes longer travel distances feasible and, on the other hand, a greater energy density enables lower battery weights and vehicle weights [38]. This can reduce the energy consumption through a lower vehicle weight that is based on its influence on the different driving resistances [39]. A higher energy density means a greater driving range for the same battery weight. In 2018, the volumetric energy density of lithium-ion batteries was between $200 \mathrm{Wh} / \mathrm{L}$ to $300 \mathrm{Wh} / \mathrm{L}$ [40] and between $400 \mathrm{Wh} / \mathrm{L}$ to $450 \mathrm{Wh} / \mathrm{L}$ on the cell level [41]. The authors of [41] forecast an energy density of $650 \mathrm{Wh} / \mathrm{L}$ to $700 \mathrm{Wh} / \mathrm{L}$ for 2023 through improvements in the production process and chemical materials used.

In addition, the gravimetric energy density of modern lithium-ion batteries lies in the range of $90 \mathrm{Wh} / \mathrm{kg}$ to $250 \mathrm{Wh} / \mathrm{kg}$ [42]. Tesla, for example, uses lithium nickel cobalt aluminum oxide batteries (NCA) [42], which, when compared to other lithium-ion batteries (e.g., lithium manganese oxide: $100 \mathrm{Wh} / \mathrm{kg}$ to $140 \mathrm{Wh} / \mathrm{kg}$ ), has a greater gravimetric energy density $(200 \mathrm{Wh} / \mathrm{kg}$ to $250 \mathrm{Wh} / \mathrm{kg})[42,43]$.

Solid-state batteries are a promising technology for a further improvement of the energy density and driving range. This technology has the potential to increase the energy density by up to $40 \%$ [44] and 70\% [45] as compared to the current state-of-the-art lithiumion batteries. Further advantages of solid-state batteries are the reduced flammability and a longer lifetime compared to batteries with liquid electrolyte [45].

The price for lithium-ion battery packs is also showing a positive development. In 2018, it stood at below $200 \$ / \mathrm{kWh}$, and Bloomberg forecasts a price of $94 \$ / \mathrm{kWh}$ for 2024 
and $62 \$ / \mathrm{kWh}$ for 2030 [46]. Thus, decreasing costs and increasing energy densities can lead to a greater driving range of future electric vehicles. Figure 6 also shows the price development of battery packs.

However, despite all of the facts that should dispel any concerns in this regard, the psychological phenomenon 'range anxiety' still exists [47-49]. This is surprising considering the driving range of modern electric vehicles and the actual mobility behavior of potential users of electric vehicles, as seen in Figure 7. Furthermore, the theory of range anxiety is presented to clarify whether this purchasing barrier is justified or not.

Range anxiety is hardly a new phenomenon. Already in 2011, [50] presented an analysis of the range anxiety that is caused by the limited range of electric vehicles. At this time, there were only 14,590 electric vehicles used worldwide [33], and their range was far shorter when compared to today's electric vehicles. This can serve to explain the existence, and prevalence, of range anxiety. For example, under ideal conditions, the Mitsubishi i-MiEV of 2012 was able to drive about $155 \mathrm{~km}$ [51]. Thus, the difference between the range of electric vehicles and the range of conventional vehicles was noticeable. In recent years, the share of electric vehicles on the road has rapidly grown and, in 2018, the threshold of five million battery electric vehicles and plug-in hybrid worldwide was exceeded [33]. The average driving range of the analyzed, current vehicles is $343.67 \mathrm{~km}$, as mentioned before. In addition, Table 4 highlights that the range of an electric vehicle correlates with, among other things, the purchasing costs.

Table 4. Correlation between purchase price and driving range. The data of the purchase prices are based on data presented on the websites of the various manufacturers.

\begin{tabular}{ccc}
\hline Category & Price Range [€] & Average Driving Range [km] \\
\hline 1 & $20,000-29,999$ & 245 \\
\hline 2 & $30,000-39,999$ & 374 \\
\hline 3 & $>40,000$ & 438 \\
\hline
\end{tabular}

For example, the Audi e-tron 55 Sportback has a driving range of $446 \mathrm{~km}$ and a purchase price between of $\$ 83,750$, depending on the vehicle features. Compared to the Audi e-tron 55 Sportback, the smart EQ fortwo has a driving range of approximately $159 \mathrm{~km}$ and a price of $\$ 21,387$. In addition, the categories in Table 4 underline the correlation. The selected vehicles of category 1 have an average driving range of $245 \mathrm{~km}$ as compared to the vehicles of category $3(438 \mathrm{~km})$. These examples underline the correlation between purchase costs and driving range. However, despite the plentiful offer for high-range vehicles, range anxiety remains an object of research in current academic publications $[52,53]$.

In his doctoral thesis [54], T. Franke analyzes sustainable mobility in the context of limited resources. One interesting finding is that drivers of electric vehicles have a theoretical safety buffer of $20 \%$ to $25 \%$ of the driving range in their mind. In other words, $20 \%$ to $25 \%$ of the available driving range are not used. For example, in the case that the driving range is $100 \mathrm{~km}$, the driver thinks that the driving range is only between $75 \mathrm{~km}$ to $80 \mathrm{~km}$. The safety buffer is caused by an incorrect perception of the actual driving range $[54,55]$.

A further study [56] concludes that range anxiety correlates with the level of experience drivers have with electric vehicles. A greater experience in driving an electric vehicle leads to less range anxiety [56]. This correlation was also found in [50]. Based on the findings of [50,56], a survey with 179 interviewees was conducted in 2017 for this paper to analyze the prevalence of range anxiety. Fifty-two of the interviewees were owners of electric vehicles and 127 interviewees owned a conventionally powered vehicle. Only $28 \%$ of the electric vehicle owners stated that they have range anxiety, as shown in Figure 8 . When compared to the electric vehicle owners, $62 \%$ of the interviewees who were not owners of an electric vehicle have range anxiety. These findings underline the results of [56] and show 
that range anxiety is a psychological phenomenon that is especially prevalent in people who have no previous experience in using electric vehicles.

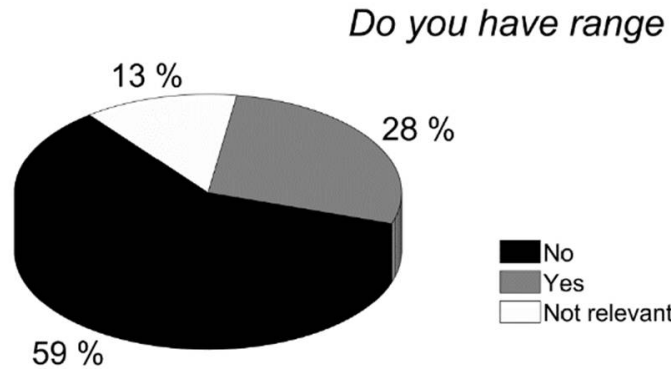

Interviewees with electric vehicle

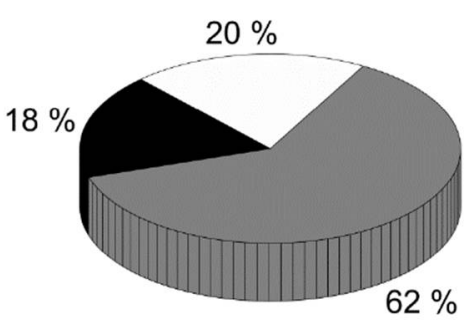

Interviewees without electric vehicle

Figure 8. Results of an own survey in the context of range anxiety.

Besides the psychological aspects, there are also technical solutions for combating range anxiety. For example, the optimization of range prediction can reduce range anxiety. In previous publications $[57,58]$, a system is presented that is able to detect payload changes of vehicles tire pressure monitoring. By knowing the current vehicle mass and by determining its payload, the calculation of energy consumption and available driving range along the route can be optimized. A further technical solution is the integration of range extenders to enhance the driving range [59]. Alternatively, the development of software solutions can also be helpful, for example, to provide the driver with information regarding nearby charging stations [60]. A wide range of parameters (vehicle weight, battery capacity, traffic volume, meteorological data, etc.) needs to be considered to precisely predict the range of electric vehicles [61]. The authors of [61] recommend e.g., the development of an advanced software solution that uses, e.g., artificial intelligence for range prediction to analyze and consider all necessary influencing parameters. In summary, while it can be said that range-prediction software has been improved in recent years, current systems still harbor a great potential for improvement regarding the integration of artificial intelligence.

Plug-in hybrid electric vehicles (PHEV) are another promising solution for overcoming range anxiety. By driving PHEVs, potential purchaser of EVs get in contact with vehicles powered by electrical energy. This growing experience with EVs enabled by driving PHEVs can lead to a reduction of range anxiety, although further investigations are needed if more detailed statements in this regard are to be made, as already asserted in [56] and in accordance with the results of our own survey.

The introduction of fast charging technologies, like the Tesla Supercharger, can also help to overcome the range anxiety [62]. Therefore, the next section will analyze the charging time of current electric vehicles to underline the potential for improvement.

\subsection{Charging Time of Modern Electric Vehicles}

The relationship between range anxiety and the available charging infrastructure is addressed and discussed in [52,62]. In these studies, the authors emphasized that an increasing number of charging stations and integration of rapid charging systems into the charging infrastructure can help to reduce the range anxiety. The natural consequence of this relationship is that increasing battery capacities and the development as well as the integration of electronic components necessary for fast charging are important topics for automobile manufactures. Another important issue is ensuring that systems for fast charging would be economical. Section 2.5 presents further details about economic aspects regarding charging infrastructure.

The charging times in EVs depend on the battery capacity and type of grid connection. For instance, charging with a DC connection can last a few minutes, while using an AC connection would take several hours. When charging using AC current, the vehicle's on- 
board charger receives alternating current (AC), which it then converts into direct current (DC), which is finally sent to vehicle battery. Charging the vehicle with DC current is done using a DC charging station, which can convert the AC current that is received from the power grid to a DC current. This charging current then bypasses the on-board charger of the EV and it is sent via a battery management system (BMS) to the battery, as instructed by the vehicle's charging control system. What this essentially means is that the charging time is not limited by the power of the on-board charger, which opens up great potential for reducing the charging time.

Using the example of a Nissan Leaf with a battery capacity of $40 \mathrm{kWh}$, Table 5 provides possible charging times with AC charging according to the charging capacity. However, this only represents an ideal case of $100 \%$ efficiency, and it neglects any losses. In the study [63], the losses of a conductive charging system were investigated in detail through an analysis of both the selected vehicle and charging station components. The losses evidently depend on AC current (10 A, losses: 17\%; $40 \mathrm{~A}$, losses: $12 \%$ ). High losses occur, especially when the transformers operate below their rated power. In the best case, a Nissan Leaf that is charged with AC current requires two hours to be fully charged. This is unacceptable for long journeys due to the extremely increased time required. Therefore, the only remaining option is DC charging. With a possible charging capacity of $50 \mathrm{~kW}$, a Nissan Leaf would be charged within $40 \mathrm{~min}$ [8].

Table 5. The charging time of Nissan Leaf with $40 \mathrm{kWh}$ battery depending on charging current and capacity [8].

\begin{tabular}{cccccc}
\hline Charging Current & DC & \multicolumn{3}{c}{ AC } \\
\hline Charging capacity $[\mathrm{kW}]$ & 50 & 22 & 11 & 3.7 & 2.3 \\
\hline Charging time $[\mathrm{h}]$ & 0.67 & 6.5 & 11.5 & 11.5 & 17.4 \\
\hline
\end{tabular}

The aging of batteries depends, among others, on the charging power. The majority of modern electric vehicles are limited to a C-rate between $1 \mathrm{C}$ and 1.5 C [49]. The C-rate defines the maximum charging and discharging current with regard to the battery capacity. Higher charging rates (e.g., between $1 \mathrm{C}$ and $4 \mathrm{C}$ ) can cause lithium plating, increasing impedance, and promoting a reduction in cell capacities [49,64]. As a result, lithium-ion batteries can age faster [64]. Additionally, the battery temperature is a further important factor that influences aging of batteries and needs to be considered [49].

The charging technology of seven modern electric vehicles was analyzed to obtain an overview of the charging time of electric vehicles. The charging times presented below refer to a charging process up to a state of charge (SoC) of $80 \%$. At charging powers between 3.6 to $50 \mathrm{~kW}$, the charging times vary from $36 \mathrm{~min}$. (VW e-Golf, $50 \mathrm{~kW}$ ) to approximately $27.5 \mathrm{~h}$ (Audi e-tron Sportback 55 quattro, $3.6 \mathrm{~kW}$ ), see Figure 9. When compared to the selected vehicles, the Porsche Taycan, e.g., can be charged by higher C-rates, e.g., approximately $3 \mathrm{C}$, at a voltage level of $800 \mathrm{~V}[49,65]$, which means that the Porsche Taycan is able to be charged by a maximum charging power of $270 \mathrm{~kW}$. This leads to a significant reduction in charging time, such that the Porsche Taycan can be charged from 5 to $80 \%$ of SoC in $22.5 \mathrm{~min}$. under ideal conditions. In other words, sufficient energy for $100 \mathrm{~km}$ can been charged within $5 \mathrm{~min}$. The effects of fast charging regarding battery aging of the Porsche Taycan and other electric vehicles need to be observed and analyzed in the coming years. 


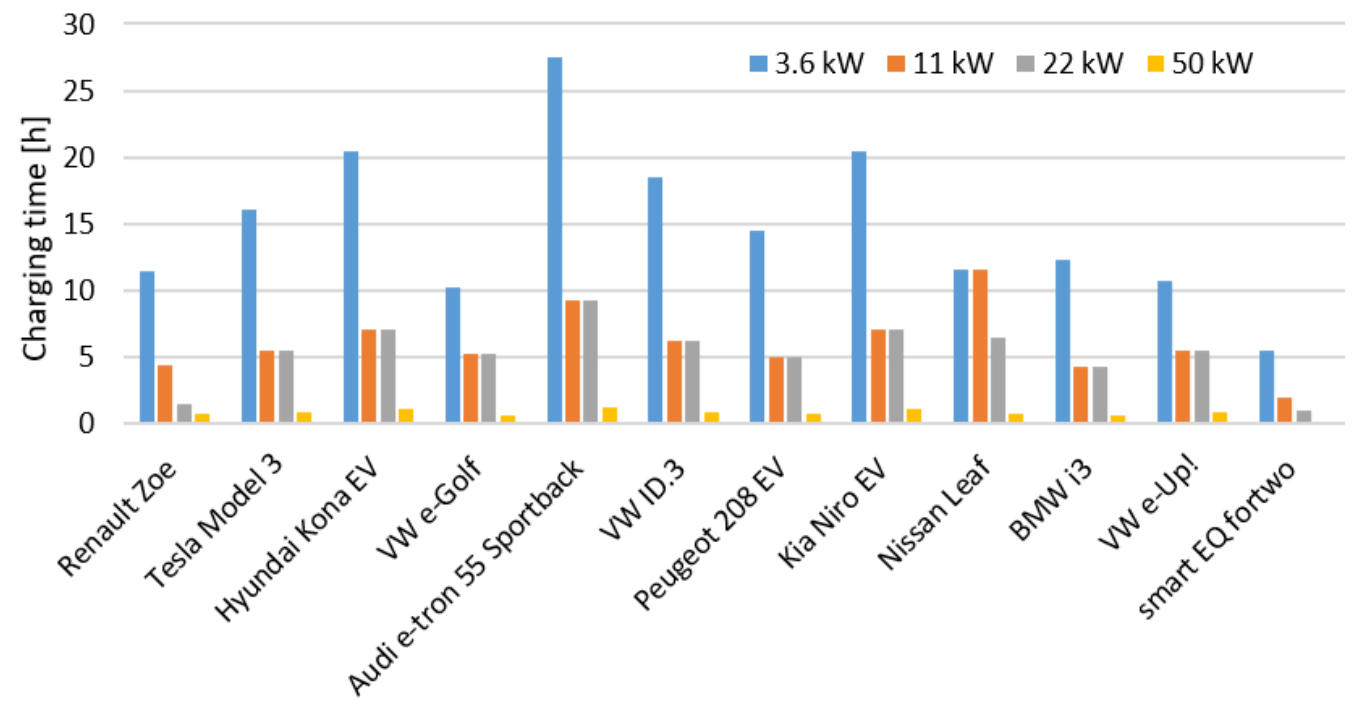

Figure 9. Charging time of current electric vehicles depending on charging power. The data of charging time is based on data provided by the manufacturers on their websites. The AC charging power $(3.6 \mathrm{~kW}-22 \mathrm{~kW})$ of some of the selected vehicles is limited by the onboard-charger. Hence, the charging time at $11 \mathrm{~kW}$ can be similar to the charging time at $22 \mathrm{~kW}$ (e.g., Kia Niro EV). In addition, some of the EVs are able to be charged by charging power above $50 \mathrm{~kW}$ (e.g., Tesla Model 3).

To win over potential buyers of electric vehicles, in the best-case scenario, the charging times for EVs need to be close to the time that is required for refueling conventional vehicles. In [66], the authors emphasize that the refueling process of fuel cell electric vehicles takes approximately between 2 to $3 \mathrm{~min}$. This quick refueling process enables current fuel cell electric vehicles to compete with conventional vehicles regarding refuel time. When compared to conventional and fuel cell vehicles, the average charging time of the analyzed modern electric vehicles is $45.6 \mathrm{~min}$. with a charging power of $50 \mathrm{~kW}$ (see Figure 9). Therefore, it can be summarized that faster charging and a greater availability of fast charging stations have the potential to increase public acceptance of electric vehicles. Based on this conclusion, the following sections will explore the significance of the charging infrastructure for the growing spread of electric vehicles.

\subsection{Charging Infrastructure}

Academic literature on the subject already highlights a number of issues that are related to the charging infrastructure for electric vehicles. Important aspects such as safety and condition assessment have been examined in order to avoid malfunctions and to ensure interoperability and functionality of the electronic components $[67,68]$. Furthermore, the impact of an installed charging infrastructure on air quality and the associated effects on human health were analyzed [69] and the possibility of combining renewable energy sources with charging infrastructure [70]. Various publications [71-74] attempt to establish models for the prediction of the demand for publicly accessible charging stations, while other studies focus on infrastructure configurations and, thus, on the technical aspect [75].

While all of these topics are indeed of great importance for a successful integration of electric vehicles into the automotive market and for increasing customer acceptance, the aforementioned publications fail to do justice to the complexity of developing a satisfactory and sustainable charging infrastructure with its numerous influencing factors. Therefore, this study seeks to look more closely at those influencing factors that play a role in the development and planning of a charging infrastructure, and shows the interactions and links between the different topics. It has the merit of also considering non-technological issues.

The main difficulty is in developing a well-networked charging infrastructure without operative experiences and, at the moment, lacking any standards. Furthermore, the technical developments for AC charger, or rather DC charger, are not completed due to 
an inability to calculable market demand in the future and the uncertainty regarding the required charging capacities. Added to these are still a few more problems to be solved, which will be further discussed in this section. The most important factors having an impact on infrastructure planning are presented to illustrate the complexity of the topic. The first segment of this section presents a comparison of the current status of Germany's EVs charging infrastructure with that of other countries. Among other things, funding programs that are intended to promote and accelerate the development of this infrastructure are mentioned. This is followed by an examination of the geographical characteristics, which determine where there is potential for the erection of charging stations. The target group determines the extent to which the charging infrastructure needs to be expanded at which location. Finally, the different charging stations that can be considered are discussed.

\subsubsection{Charging Infrastructure-Current State}

The current status of the respective charging infrastructure varies significantly from state to state. Here, the focus is on the charging infrastructure in Germany how it compares to that of other countries.

\section{Germany}

The current charging infrastructure must be expanded in order to ensure a smooth energy supply. As the number of electric vehicles used on the road rises, so must the number of charging points. According to Federal Motor Transport Authority, there are currently 194,163 electric vehicles registered in Germany (as compared to 83,175 electric vehicles in 2019) [35], which have access to 23,800 charging stations [76]. The number is a rough estimate of the active charging stations in Germany, but not all of them comply with the charging station ordinance (LSV). The number of officially registered charging stations according to LSV is 14,706 .

In Germany, there is currently still a difference in the spatial coverage of publicly accessible charging stations. This is also shown in Figure 10, where the number of charging stations per federal state is shown on the left and the distribution along the freeways on the right. Especially, the mostly rural areas in the east (e.g., Brandenburg, Saxony-Anhalt, and Mecklenburg-Western Pomerania) have a lower density of charging stations, while the expansion of the network in Germany's major metropolises (e.g., Berlin, Hamburg, Cologne, Dusseldorf, and Dortmund) is already well underway. Similarly, coverage in the German highway network is already relatively dense. Competition for the best charging stations (Figure 10, black points) is already visible along the federal highways (Figure 10, blue lines). However, regional differences are also evident here. The expansion along freeways is still lacking in Brandenburg, Saxony-Anhalt, and Mecklenburg-Western Pomerania, with only a few charging stations.

It is difficult to quantify the extent to which the charging infrastructure needs to be expanded to noticeably influence social acceptance. Social acceptance depends on the personal perception of the people. Acceptance will not improve as long as they are concerned about looking for charging stations or being required to plan long waiting times for charging their vehicle. It is necessary that these very people who harbor such doubts come into contact with electric vehicles and gain experience or hear positive experiences from other people. The vehicle technology itself is mature for everyday use; only the costs would need to be reduced.

In Directive 2014/94/EU (Alternative Fuels Infrastructure), the European Union obliges its member to develop a national strategy for achieving a nationwide and balanced charging infrastructure [77]. Consequently, the German Federal Ministry of Transport and Digital Infrastructure published the funding directive 'Charging Infrastructure for Electric Vehicles in Germany' in February 2017. With a funding volume of $€ 300$ million, at least 15,000 charging stations were to be established by end of 2020 [78]. In these efforts, the focus is specifically on the expansion of the network of publicly accessible charging 
stations, with $€ 200$ million to be invested in normal charging points ( $3.7 \mathrm{~kW}$ to $22 \mathrm{~kW}$ ) and 100 million $€$ in the fast charging points $(>22 \mathrm{~kW})$.
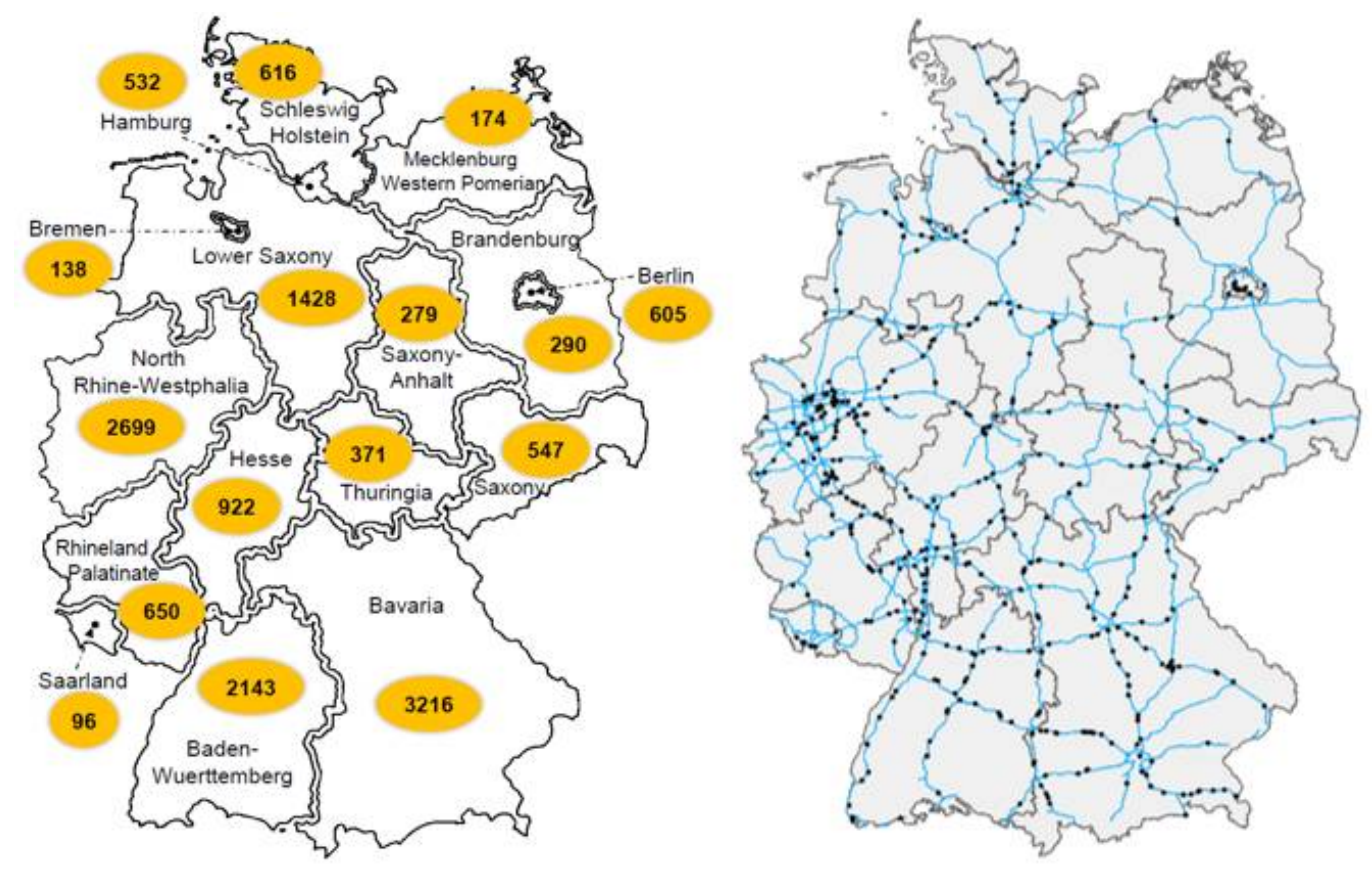

Figure 10. Number of charging stations per federal state (left) and along the freeways [76] (right) in Germany (2019).

In October 2019, the German Federal Government published a master plan that was based on the 'Climate Protection Program 2030', which defines goals and measures for the development of charging infrastructure. Among other things, the plan envisages the construction of one million publicly accessible charging stations by 2030 [79]. Various calls for funding are to be published by 2025 to realize the high number of one million charging stations. These calls for funding do not only refer to publicly accessible charging stations, but also to private charging stations. In the first instance, up to 65,000 publicly accessible charging stations are to be built by 2021 with a volume of funding of $€ 3$ billion, and a further $€ 50$ million will be invested in the expansion of private charging stations from 2020.

In 2019 , over $64.7 \%$ of EV owners stated that they would prefer to charge at home, $15.1 \%$ at publicly accessible charging points, $7.4 \%$ at work, and $12.8 \%$ were still undecided [80]. Consequently, focus should be restricted to the development of an infrastructure of publicly accessible charging stations, but also on the private charging segment. For this reason, the purchase of charging stations is subsidized as of November 2020. After submission of the application and proof of installation, applicants receive a subsidy of $€ 900$ [81]. In addition to the purchase price, the assembly, connection, and installation work will be included in the subsidized costs.

As long as people have the option of charging at home, they will prefer it, because it means more comfort (free parking space, familiar surroundings, no waiting times, uncomplicated billing, and car is better protected). Charging stations that are accessible to the broad public, on the other hand, are relevant for those who have no option to charge at home or at work or for tourists.

Various studies from the private sector, politics, and science all assess the amount of charging stations required to satisfy demand for power for EVs at about the same number [79]. There were 136,617 electric vehicles registered in Germany in 2020, according to the German Federal Motor Transport Authority [6]. Quantifying installed charging stations, on the other hand, is more difficult, because only those charging stations are officially counted, which comply with the charging station ordinance (LSV) and have been 
successfully registered with the German Federal Network Agency. As a result, the German Federal Network Agency count 14,706 charging stations that are installed in Germany.

Worldwide

In the following, some selected data are presented to give the reader an overview of the number of charging points for EVs worldwide and to provide an assessment of how great the global demand for charging stations is.

According to the U.S. Department of Energy [82], the United States of America had 31,826 charging station locations on 26 September 2020. The majority $(28,324)$ of these charging locations support level 2 charging ( $3.3 \mathrm{~kW}$ to $3.6 \mathrm{~kW} \mathrm{AC}$ ) and 4799 of them are locations with DC fast charging stations (above $50 \mathrm{~kW} \mathrm{DC)} \mathrm{[82,83].}$

In [83], the authors emphasize that there is a gap of charging capacity the USA corresponding to three million electric vehicles, which are expected to enter into active use by 2025 . The charging infrastructure needs to grow by about $20 \%$ annually to handle this expected number of electric vehicles [83]. Based on the forecasts that are presented in [84], California needs to have 229,000 to 279,000 chargers for the charging of an expected amount of 1.3 million electric vehicles by 2025 [84]. These data highlight the expansion of the charging infrastructure that is necessary in the USA.

In November 2019, 202,000 publicly accessible charging stations have been installed in the EU and Switzerland [85]. Approximately $61 \%$ of the chargers in the EU are AC chargers with $11 \mathrm{~kW}$ or $22 \mathrm{~kW}$ and approx. 5.4\% are CCS (combined charging system) fast chargers [85]. The other $33.6 \%$ are one-phase AC charger with $3.7 \mathrm{~kW}$ or $7.4 \mathrm{~kW}$. In a scenario that is shown in [85], the authors forecast 1.2 to 1.3 million charging points in 2025 and this number is expected to double by 2030 ( 2.2 to 2.9 million).

At the beginning of 2019, 2449 charging stations and 12,365 charging points were installed in Norway (2.8 million total registered vehicles, of which 370,000 are EVs $(13.2 \%)$ ), and the Netherlands had 47,669 charging points (publicly accessible and semi-publicly accessible) by September 2019 (8.37 million total registered vehicles, of which 171,300 are EVs (2\%)) [86-90]. When compared to 14,706 charging stations in Germany (47.09 million total registered vehicles, of which 83,175 are EVs $(<1 \%)$ ), and considering the geographical size of Germany, the Netherlands is one step ahead and one of the leading providers of charging stations in the EU [91]. These data highlight the need for quickly expanding the network of charging stations in Germany.

China is the global leader in the size of its charging infrastructure for electric vehicles (3.81 million EVs, 206 million total registered vehicles). In October 2019, the total number of installed publicly accessible charging stations in China was 478,000 [92]. In summary, while it can be said that the global charging infrastructure has expanded in recent years, there is still a gap in charging stations and, in light of the forecasts for the sales volume of electric vehicles in the years to come, the installation of charging stations needs to be accelerated (e.g., by funding programs).

\subsubsection{Geographic Characteristics}

The existing regional infrastructure forms the basis for future expansion. All of the regions are characterized by their geographical conditions (e.g., rivers, mountains, forests), and the current infrastructure has developed accordingly to accommodate these features. In addition, further infrastructure characteristics, such as central transport axes, central traffic flows, important points of interest (POIs), and commercial locations, must be identified, recorded, and considered [93].

The first step can be a rough mapping of the desired distribution of regional charging stations, also referred to as macroplanning [94]. Heavily frequented locations should be chosen from a user and economic point of view. It is also important to eliminate geographical gaps.

This is followed by micro-planning, in which the exact location of charging stations is specified. When choosing the location of charging stations, the scarcity of space is an 
important aspect. Big cities already suffer from a shortage of parking spaces, so that limiting the space more by constructing charging stations might be unacceptable for many cities. Mainly, the selection is not made according to need and suitability, but according to availability. The following criteria, which are specified by the municipal authorities (involved actors: civil engineering office, monument protection authority, road traffic authority, public order office, network operator, and property management), should be met for a location concept, among others, [95]:

- Conformity with road traffic law.

- Consideration of monument zones.

- Visibility, busy, and well-signposted roads.

- Publicly accessible locations at all times.

- Accessible locations in all seasons (especially in winter).

- Safe locations with night-time lighting.

- Access to low voltage or medium voltage network depending on charger type.

- Wherever possible, charging stations approachable from both directions, no one-way streets.

- Preference for major roads to protect residential areas.

- Reliable mobile network or LAN cable for connection to a backend system.

There are several ways to charge an electric vehicle. Ultimately, a future-optimized charging infrastructure will offer several of these charging technologies, focusing on those that perfectly suit the relevant location, charging needs, charging time, power supply, and cost considerations. Furthermore, it is important not to underestimate the influence of private charging points. The ability to charge electric vehicles overnight at the owner's home is both convenient and cost-effective.

\subsubsection{Target Group}

Another important aspect, in addition to geographical characteristics, is the consideration of group-specific needs for each region. Different charging capacities may be considered, depending on the customer group. Accordingly, factors, such as usage (all-year, seasonal), duration of stay, or type of access/payment (e.g., card, smartphone app), must be taken into account. A distinction can be made between three categories [96,97].

- Citizens, inbound commuter, and local companies:

These vehicle owners will mainly use their private charging points at home or those of the employer at work all year long (see Figure 11), which means that there is always enough time to charge the vehicle (by day: at work; by night: at home) and a charging station with low capacity would be adequate for this kind of usage. One major challenge regarding charging stations for the above-mentioned countries (2.5.1) is the provision of charging stations at apartment buildings. Not all of the apartment buildings have the possibility to install charging stations due to lack of parking space. The problem in cities discussed above is quite common and it was investigated in the study [98]. In these cases, residents would need to access publicly accessible charging stations (e.g., city centers, industrial parks, large parking lots, and parking garages). Figure 11 summarizes the preferred charging locations of private users.

\section{- Tourists:}

Tourists usually congregate at a region's hotspots. For this particular group, the charging infrastructure of those places (e.g., POIs, tourism information offices, city centers, and hotels) should be expanded. The length of stay varies, depending on the attraction, and it is usually seasonal.

In turn, tourists can be divided into two categories: day visitors and overnight guests. Day visitors cover medium-long distances and they require a charging possibility at the destination (e.g., large parking lot). In the off-season, such parking lots are often not used at all, which is economically inconvenient. Furthermore, the time of stay is too short to fully charge the vehicle with low capacity. In this case, it is questionable as to whether it 
is worthwhile to invest in AC chargers with a high capacity or in DC charging stations, especially during seasonal operation. Overnight guests cover long distances and they need a charging station at their destination. Charging stations directly at the hotel could be an option, so that guests can also charge overnight, and they do not need to rely on other charging stations at their destination.

Access / payment should be kept as uncomplicated as possible (e.g., smartphone, credit card), so that all customers of any nationality can use the charging stations.

- Through traffic:

In the case of a short stay to charge an electric vehicle at publicly accessible charging points (e.g., freeways, thoroughfares), only quick chargers with high charging capacity are suitable. The interest of this group is mainly to resume their journey as quickly as possible. Access/payment should be as simple as possible (e.g., smartphone, credit card).

For target groups, like tourists and through traffic, publicly accessible charging locations are presented in Figure 11 on the right side.

Customer needs are without a doubt a very important aspect to consider when implementing a useful and economically viable charging infrastructure.

Finally, consumer demand is influenced by factors, such as technological capabilities, changes in modal split, energy and power availability, population growth, energy consumption, and market structures.

\begin{tabular}{|c|c|c|c|c|c|c|}
\hline \multicolumn{3}{|c|}{$\begin{array}{c}\text { Private locations } \\
60-85 \%\end{array}$} & \multicolumn{4}{|c|}{$\begin{array}{l}\text { Publicly accessible locations } \\
\qquad 15-40 \%\end{array}$} \\
\hline$\square$ & $\begin{array}{|lll|}0 & 0 & 0 \\
0 & 0 & 0 \\
0 & 0 & 0 \\
& 0 & 0 \\
\end{array}$ & 国 & 呬，睢 & & $\exists$ & \begin{tabular}{|l|l|l|}
$\mathrm{g}$ & $\mathrm{P}$ & $\mathrm{E}$ \\
$\mathrm{g}$ & $\mathrm{g}$ & $\mathrm{g}$ \\
\end{tabular} \\
\hline $\begin{array}{l}\text { Garage or } \\
\text { parking } \\
\text { space at } \\
\text { home }\end{array}$ & $\begin{array}{l}\text { Parking spaces } \\
\text { (e.g. apartment } \\
\text { buildings and } \\
\text { blocks) }\end{array}$ & $\begin{array}{l}\text { Company } \\
\text { parking space }\end{array}$ & $\begin{array}{l}\text { Inner-city } \\
\text { charging } \\
\text { station }\end{array}$ & $\begin{array}{l}\text { Charging } \\
\text { station on } \\
\text { traffic routes } \\
\text { (e.g. } \\
\text { freeways, } \\
\text { federal roads) }\end{array}$ & $\begin{array}{l}\text { Customer } \\
\text { parking space } \\
\text { or multi-storey } \\
\text { car parks (e.g. } \\
\text { shopping } \\
\text { centers) }\end{array}$ & $\begin{array}{l}\text { Roadside, } \\
\text { public parking }\end{array}$ \\
\hline \multicolumn{3}{|c|}{ Regular and night charging } & \multicolumn{2}{|c|}{ Load in between } & \multicolumn{2}{|c|}{ Fast charging } \\
\hline
\end{tabular}

Figure 11. Private and publicly accessible charging locations [99].

\subsubsection{Charging Station}

Regarding charging stations, a distinction must be drawn between two types of charging procedures. Conductive charging technology enables the charging of electric vehicles via a charging cable, which establishes the connection from the vehicle to the power grid. Inductive chargers, on the other hand, wirelessly transmit electrical energy through the air gap using an electromagnetic coupling. Figure 12 shows both of the charging options, whereby a distinction is still made between AC and DC charging in the conductive version, whereas inductive charging always uses an AC current due to the system's requirements. In addition to typical charging performance, the maximum possible performance values based on current standards are also given.

Each type of charging procedure requires certain technical equipment technology (e.g., charging station hardware, vehicle connectors and inlets, plugs, and electric meters), and it is generally considered an advantage for operators and system designers to consider compatibility and interoperability. The standards ensure uniform requirements and support the development of infrastructure for electric mobility; such standards are also continuously adapted to technological innovations to ensure relevance in the face of changing circumstances. Some of the most important international standards so far are explained below and they are summarized in Tables 6 and 7. 


\begin{tabular}{|c|cc|}
\hline \multicolumn{2}{|c|}{ Inductive } & \multicolumn{2}{c|}{ Conductive } \\
\hline AC charging & AC charging & DC charging \\
\hline $3.7 \mathrm{~kW}$ & $3.7 \mathrm{~kW}$ & $50 \mathrm{~kW}$ \\
$7.4 \mathrm{~kW}$ & $11 \mathrm{~kW}$ & $150 \mathrm{~kW}$ \\
$11 \mathrm{~kW}$ & $22 \mathrm{~kW}$ & $400 \mathrm{~kW}$ \\
$22 \mathrm{~kW}$ & $44 \mathrm{~kW}$ & \\
\hline & & Type 2 Combo 2 \\
\hline
\end{tabular}

Figure 12. Overview of charging stations with the respective typical charging capacities [99].

\section{Conductive Charging}

Conductive charging using AC current can achieve power values of up to $44 \mathrm{~kW}$ (three-phase) using a Type 2 plug, whereby charging with up to $22 \mathrm{~kW}$ is defined as normal charging, and charging with between $22 \mathrm{~kW}$ to $44 \mathrm{~kW}$ is defined as fast charging (Figure 12). In the future, DC (fast) charging with a Combo 2 plug will be able to transfer power of up to $400 \mathrm{~kW}$ [99].

Charging an electric vehicle using AC power with $22 \mathrm{~kW}$ or $44 \mathrm{~kW}$ could, at least theoretically under ideal conditions, be completed in one to two hours, depending on the battery capacity or charge level. However, the AC charging variant is not supported for even faster charging by car manufacturers, because the corresponding rectifier, which must be integrated into vehicles, is very expensive. Charging the vehicle using DC power does not require this rectifier to be installed in the vehicle, as it is included in the charging station. For this reason, car manufacturers rely on DC chargers for fast charging, so electric vehicles can be charged in less than $20 \mathrm{~min}$. at a maximum power of $150 \mathrm{~kW}$ [100]. It is advisable to only charge batteries to $80 \%$ of the maximum SoC during fast charging to protect the batteries and to extend their service life [101].

Figure 13 and Table 6 are intended to provide an overview of standards regarding conductive charging. In Figure 13, corresponding standards are assigned to the components and, in Table 6, they are listed in detail with their subchapters.

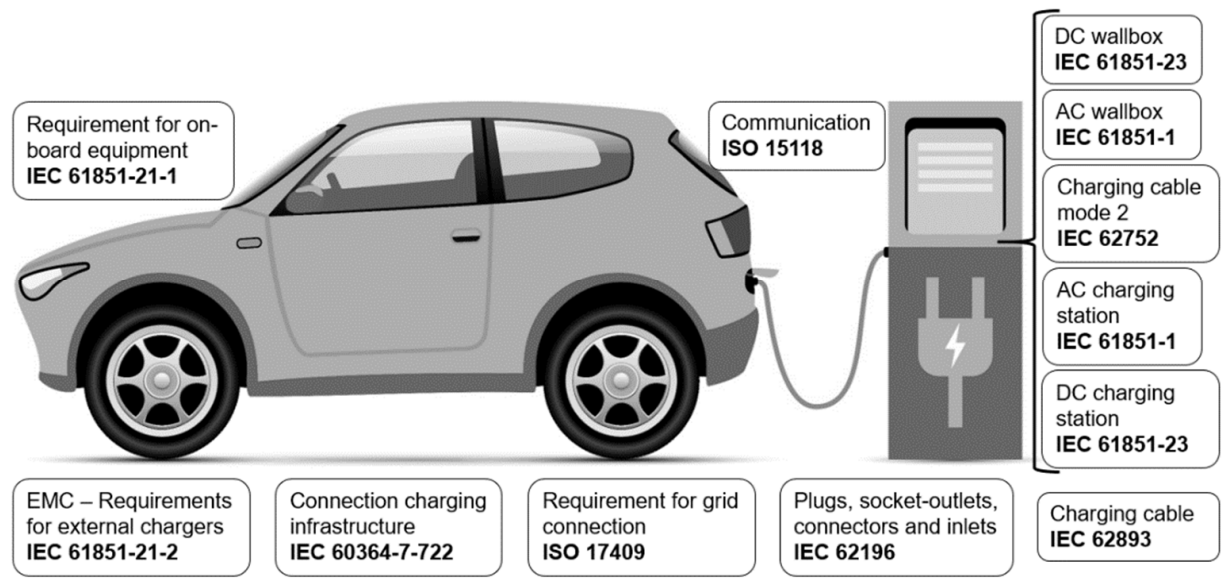

Figure 13. Conductive charging for electric vehicles with the relevant standards by part [99].

General safety requirements for a charging infrastructure are described in IEC 618511 [102]. This standard applies to all of the components used in charging infrastructures, such as the charging cable, AC and DC wall boxes, charging poles, plugs, and sockets. 
The IEC 61851-23 standard has been specifically developed for DC charging devices, describing charging processes, and special requirements [102].

Plugs and sockets required to connect an electric vehicle to the infrastructure for AC charging are specified in IEC 62196-2. IEC 62196-3 applies to DC plugs and sockets. The general requirements that are listed in IEC 62196-1 are binding for both standards [103]. The plugs and sockets described in these standards are part of the combined charging system and have already been specified in European Union Directive 2014/94/EU as a minimum requirement for the equipment of charging points in publicly accessible areas [77].

In the standard ISO 15118 (International Organization for Standardization), the required hardware, process, and protocol are specified for communication between vehicles and the charging infrastructure for various application scenarios. This includes load management, automatic authentication of customer, and data transfer for invoicing [104].

IEC 62752 describes requirements for the charging cable for charging mode 2, including the integrated control and protection device for charging at household and industrial sockets [105].

The requirements for charging cables are described in IEC 62893 and vehicle safety requirements for connection to an external power supply are specified in ISO 17409 [106,107].

The issue of the electromagnetic compatibility of chargers that are installed in EVs is laid down in IEC 61851-21-1. Part 2, i.e., IEC 61851-21-2, describes these requirements for chargers operating outside the vehicle. Both of the standards specify tests to be carried out under defined load conditions and they regulate requirements regarding immunity and emission [102].

The connection of charging stations to the electrical distribution network is specified in IEC 60364-7-722 [108].

Table 6. List of standards regarding conductive charging.

\begin{tabular}{|c|c|}
\hline Standard & Content \\
\hline IEC $^{1} 61851$ [102] & $\begin{array}{c}\mathrm{EV}^{3} \text { conductive charging system } \\
\text { - Part 1: General requirements } \\
\text { - Part 21-1: EV on-board charger } \\
\text { EMC requirements for conductive connection to AC/DC supply } \\
\text { - Part 21-2: EV requirements for conductive connection to an AC/DC supply } \\
\text { - EMC requirements for off-board EV charging systems } \\
\text { - Part 23: DC electric vehicle charging station }\end{array}$ \\
\hline IEC 62196 [103] & $\begin{array}{c}\text { Plugs, socket-outlets vehicle connectors and vehicle inlets-Conductive } \\
\text { charging of EVs } \\
\text { - Part 1: General requirements } \\
\text { - Part 2: Dimensional compatibility and interchangeability requirements for } \\
\text { AC pin and contact-tube accessories } \\
\text { - Part 3: Dimensional compatibility and interchangeability requirements for } \\
\text { DC and AC/DC pin and contact-tube vehicle couplers }\end{array}$ \\
\hline IEC 62752 [105] & $\begin{array}{l}\text { In-cable control and protection device for mode } 2 \text { charging of electric } \\
\text { road vehicles }\end{array}$ \\
\hline IEC 62893 [106] & Charging cables for EVs for rated voltages up to and including $0.6 / 1 \mathrm{kV}$ \\
\hline ISO $^{2} 15118$ [104] & $\begin{array}{c}\text { Road vehicles } \\
\text { - Vehicle to grid communication interface }\end{array}$ \\
\hline ISO 17409 [107] & $\begin{array}{l}\text { Electrically propelled road vehicles } \\
\text { - Conductive power transfer } \\
\text { - Safety requirements }\end{array}$ \\
\hline IEC 60364 [108] & $\begin{array}{c}\text { Low-voltage electrical installations } \\
\text { - Part 7-722: Requirements for special installations or locations-Supplies } \\
\text { for EVs }\end{array}$ \\
\hline
\end{tabular}

${ }^{1}$ International Electrotechnical Commission (IEC) ${ }^{2}$ International Organization of Standardization (ISO) ${ }^{3}$ Electric vehicle (EV). 
Furthermore, uniform user guidance with standardized symbols ensures easy to understand and internationally uniform orientation. Graphical symbols are used, among others, for user interface, human-machine interaction, and safety labeling.

\section{Inductive Charging}

Inductive charging of passenger vehicles and light commercial vehicles is possible with performance values of up to $22 \mathrm{~kW}$ already today (Figure 12) [99].

The wireless charging of electric vehicles is another customer requirement for making the use of electric vehicles as convenient as possible. However, the challenges to realizing this technology are high. The installation space that can be considered for a wireless charging system in the electric vehicle is limited, and different vehicle types have very different ground clearances, which also depend on the loading condition of the vehicle.

Despite such obstacles to implementation, people tend to favor wireless charging. The ease of use is considerably higher, as charging is automatic, with no mechanical connection, such as a cable and plug being required. This means that any incompatibility problems between the charging cable and the plug are completely circumvented. The wireless charging system also offers the advantage of being resistant to vandalism [109]. Unlike plug-in charging systems, the wireless charging systems can be installed underground without external equipment on the street level or exterior vehicle modules. This helps to eliminate the hassle and also reduces the cost of repairing charging stations and handling bulky charging cables [110,111]. Furthermore, the system cannot be affected by bad weather conditions, and it requires comparatively less repairs. Snow or water has no effect on the charging process and, with no moving parts, the system is not susceptible to suffering from the effects of dirt or frozen elements [110,112]. All of these advantages make inductive charging a system that is designed to meet the needs of the actual behavior of a user and the environmental conditions; meaning that the design can cope with high and low temperatures, snow, ice in winter, as well as the conditions that occur in the fall when leaves cover the ground. Charging is not affected in any way by non-ferrous magnetic material that affects power transmission, such as leaves, water, ice, and snow.

The general requirements for inductive charging systems are described below. The most important standards are assigned to the corresponding components of the charging system in Figure 14 and they are listed in Table 7 with the corresponding subchapters.

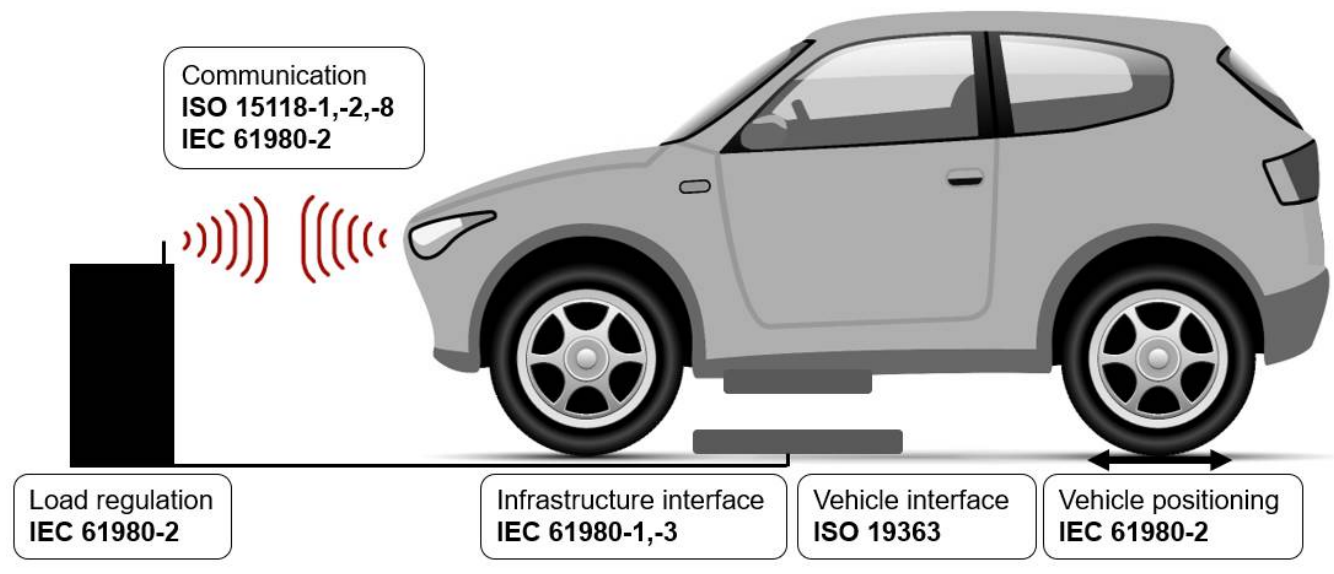

Figure 14. Inductive charging for electric vehicles with respective standards [99].

For interoperable and efficient power transmission, requirements for compensation, and resonance conditions on the vehicle and infrastructure side, must be specified in a coordinated manner. Similarly, specifications for coil position on parking lots must be provided, while taking different mounting options of the coil on vehicles into account. ISO 19363 describes the vehicle-side requirements for wireless charging and IEC 61980-3 the infrastructure side $[113,114]$. 
Another aspect to be taken into account is that a publicly accessible space demands robustness and functionality under all expected weather and usage conditions. IEC 61980-1, $-2,-3$ take this aspect into account using appropriate test procedures [114].

IEC 61980-2 describes the requirements for the fine positioning of the vehicle relative to the primary coil [114]. Such fine positioning is achieved using an additional magnetic or electromagnetic signal that is emitted by the vehicle and detected by the infrastructure unit.

The communication applications under consideration are described in IEC 61980-2 and in ISO 15118-1. The corresponding charging process is explained in IEC 61980-2 [114]. The associated communication protocol and corresponding requirements are specified in ISO 15118-2 [104]. WLAN technology according to IEEE 802.11n is used for data transmission, as defined in ISO 15118-8 [104].

Moreover, technical electromagnetic compatibility limit values for wireless charging from CISPR 11 must be observed [115]. The limits are defined in IEC 62764-1 and they apply to electromagnetic fields (EMF) [116].

Table 7. List of Standards regarding inductive charging.

\begin{tabular}{|c|c|}
\hline Standard & Content \\
\hline ISO $^{1} 19363$ [113] & $\begin{array}{l}\text { Electrically propelled road vehicles } \\
\text { - Magnetic field wireless power transfer } \\
\text { - Safety and interoperability requirements }\end{array}$ \\
\hline IEC $^{2} 61980$ [114] & $\begin{array}{c}\qquad \mathrm{EV}^{4} \text { wireless power transfer systems } \\
\text { - Part 1: General requirements } \\
\text { - Part 2: Specific requirements for communication between electric } \\
\text { road vehicle and infrastructure } \\
\text { - Part 3: Specific requirements for the magnetic field wireless power } \\
\text { transfer systems }\end{array}$ \\
\hline IEC 62764 [116] & $\begin{array}{c}\text { Measurement procedures of magnetic field levels generated by } \\
\text { electronic and electrical equipment in the automotive environment } \\
\text { with respect to human exposure } \\
\text { - Part 1: Low-frequency magnetic fields }\end{array}$ \\
\hline CISPR $^{3} 11$ [115] & $\begin{array}{l}\text { Industrial, scientific and medical equipment } \\
\text { - Radio-frequency disturbance characteristics } \\
\text { - Limits and methods of measurement }\end{array}$ \\
\hline ISO 15118 [104] & $\begin{array}{c}\text { Road vehicles } \\
\text { - Vehicle to grid communication interface } \\
\text { - Part 1: General information and use-case definition } \\
\text { - Part 2: Network and application protocol requirements } \\
\text { - Part 8: Physical layer and data link layer requirements for wireless } \\
\text { communication }\end{array}$ \\
\hline
\end{tabular}

${ }^{1}$ International Organization of Standardization (ISO) ${ }^{2}$ International Electrotechnical Commission (IEC) ${ }^{3}$ Comité International Spécial des Pertubations Radioélectriques (CISPR) ${ }^{4}$ Electric vehicle (EV).

\section{Cost Comparison of Charging Stations}

Table 8 presents an overview of the costs of different charging possibilities for comparison. All other data are from 2019, except for the cost of the wireless charging system (WCS) (2018) [117].

There is an extreme price difference between AC chargers and DC chargers. The expensive rectifiers can explain these much higher costs of DC chargers, which, in this kind of charging system, are installed in the charging stations rather than in the vehicles.

Two charging points of a DC charger $(50 \mathrm{~kW})$ are twice to five times more expensive than two charging points of an $\mathrm{AC}$ charger ( $11 \mathrm{~kW}$ to $22 \mathrm{~kW})$ and they entail approximately twice as much annual costs. In addition to the installation, commissioning, and maintenance of the DC charging stations, cost factors that arise at other areas, such as toilets, support for operating personnel, maintenance, cleaning, lighting, and security, also have 
to be taken into account. However, these costs are difficult to determine and calculate, and they will require further investigation in the future. Eight charging points of a DC charger cost a total of $€ 500,000$ to 650,000 [76]. Comparing an AC charger with charging capacity of $3.7 \mathrm{~kW}$ to a WCS with a charging capacity of $3.7 \mathrm{~kW}$, it is easy to see that the hardware of the WCS is twice as expensive as a conventional AC charging station. This is partly due to the fact that WCS are not nearly as well-established on the automotive market so far as plug-in charging stations. Implementing a WCS requires a plethora of issues to be clarified first, such as EMC, EMCU, interoperability, and standardization. The cost data of the WCS come from BMW, which offers the inductive charging system as a luxury feature for the BMW 530e iPerformance [117]. Accordingly, the technology of WCSs must be further developed in order to make them suitable for the automotive market, and the cost of DC chargers must be reduced, so that fast charging is not only possible at selected rest stops.

Table 8. Investment costs of different charging devices in Germany $[76,96,117]$.

\begin{tabular}{|c|c|c|c|c|c|}
\hline \multirow[b]{2}{*}{$\begin{array}{c}\text { Charging capacity } \\
{[\mathrm{kW}]}\end{array}$} & \multirow{2}{*}{$\begin{array}{c}\text { WCS }^{1} \\
3.7\end{array}$} & \multirow{2}{*}{$\begin{array}{c}\text { Wallbox } \\
>3.7\end{array}$} & \multirow{2}{*}{$\begin{array}{c}\text { AC Charger } \\
11 \text { to } 22\end{array}$} & \multicolumn{2}{|c|}{ DC Charger } \\
\hline & & & & 50 & 150 \\
\hline Charging points & 1 & 1 & 2 & 2 & 8 \\
\hline Hardware [€] & 3205 & 450 to 1200 & 2500 to 8000 & $\begin{array}{c}15,000 \text { to } \\
30,000\end{array}$ & n.a. \\
\hline $\begin{array}{c}\text { Grid connection costs } \\
{[€]}\end{array}$ & up to 2000 & up to 2000 & up to 2000 & $\begin{array}{l}5000 \text { to } \\
15,000\end{array}$ & n.a. \\
\hline Approval [€] & up to 1000 & up to 1000 & 500 to 1000 & $\begin{array}{l}1500 \text { to } \\
15,000\end{array}$ & n.a. \\
\hline $\begin{array}{c}\text { Installation/Signage } \\
{[€]}\end{array}$ & up to 1000 & up to 1000 & 1500 to 3000 & $\begin{array}{l}3500 \text { to } \\
20,000\end{array}$ & n.a. \\
\hline $\begin{array}{l}\text { Investment } \\
\left(\mathrm{CAPEX}^{2}\right)[€]\end{array}$ & 7205 & 4450 to 5200 & $\begin{array}{l}6500 \text { to } \\
14,000\end{array}$ & $\begin{array}{c}25,000 \text { to } \\
80,000\end{array}$ & $\begin{array}{c}500,000 \text { to } \\
650,000\end{array}$ \\
\hline $\begin{array}{c}\text { Service/Backend } \\
\left(\text { OPEX }^{3}\right)[€ / a]\end{array}$ & 1000 & 1000 & 1500 & 3000 & n.a. \\
\hline
\end{tabular}

${ }^{1}$ Wireless Charging System (WCS) ${ }^{2}$ Capital Expenditure (CAPEX) is the money a company spends to buy, maintain or improve its fixed assets. ${ }^{3}$ Operational Expenditure (OPEX) are ongoing costs for running a product, business or system.

\subsubsection{Access and Payment}

Access to charging stations is closely linked to the various methods of payment. A fundamental problem is the large amount of small charging point operators, who have implemented different access and payment procedures [118]. Therefore, it would be advisable to establish a nationally and internationally harmonized procedure for access and payment, so that customers be enabled to charge anytime and anywhere independent of charge point operators. The following is a brief outline of some of the advantages and disadvantages of different methods of access and payment.

\section{- $\quad$ RFID card:}

Operation via an RFID (radio-frequency identification) card is very simple. With this access method, a contract between the user and the operator had already been concluded. However, the payment amount is debited from the user's account on a fixed date and no direct payment is possible after the charging process. In this case, the user would be bound to the respective contracting provider and it could not use any other provider's charging station. Furthermore, the RFID card could be used as a multifunctional card, for example, by unlocking the charging plug.

- Smartphone (App/SMS): 
Smartphones offer the user more access to the provider's charging stations and the ability to pay directly as well as contactless. Nevertheless, access via smartphone can be somewhat more time-consuming, as the user may be required to register or log in first for each charging station operator.

- Giro/credit card:

The use of credit cards allows for contactless payment, which is preferable from a hygienic point of view. It is also possible to pay directly. However, costs for card terminals are high (retrofitting: up to $€ 2360$ [119], new: up to $€ 15,000$ [120]).

- Cash:

While it is true that cash offers the advantage of payment taking place directly, the implementation of receptacles for coins and banknotes is cost-intensive (used: $€ 900$, new: $€$ 7500 [120]). Furthermore, the machines would require regular emptying, which would only be economical if many charging stations are located close together. Furthermore, charging process can be aborted by opening the vehicle, meaning a loss of debit. It would be much more cumbersome with coin-operated machines to get back to your credit balance.

With contactless payment becoming increasingly popular, the smartphone and credit card options are the simplest options. RFID would also be an option with a different card for every operator. The implementation of cash machines is comparatively expensive and regular emptying is uneconomical.

\subsubsection{Pricing}

At the time of writing, no uniform pricing concept has not yet been established, as there is still no noteworthy market for it. In principle, two concepts can be considered: first, a pricing method, in which the amount of energy delivered is billed, and, secondly, a pricing method, in which only the charging time is considered.

If the object of invoicing is the amount of electricity delivered, the legal requirements of calibration law must be observed. This means that, at any point in time, the energy used must be verifiable by the user. For this purpose, calibrated and visible electricity meters must be installed. The measurement of direct current is problematic as compared to the measurement of alternating current due to the lack of certified electricity meters. Furthermore, tamper-proof data transmission must be ensured.

One potential disadvantage of this concept is that the user has no reason to remove the vehicle from the charging station after the completion of the charging process, which could be a problem in big cities or in busy regions. This problem would not exist if billing was made based on the duration of charge. Another alternative could be a combination of pricing charging time and amount of electricity delivered. First, the payment is based on the delivered quantity. Once the vehicle is fully charged, payment is based on the time the vehicle blocks the charging station. As a result, vehicle owners are charged for every additional minute they block others from charging, giving them extra incentive to leave the charging point.

The implication here is that pricing can influence the behavior of customers. For example, regions suffering from a shortage of parking spaces could control the duration of stay of vehicles at charging stations via pricing [121].

\subsubsection{Backend and Roaming}

The so-called backend system is responsible for monitoring and remote maintenance of the installed charging stations. The charging station sends their current status at regular intervals to the backend system, although this communication also works in opposite direction. For example, in the event of a fault, the backend system may send a reset command to the charging station. For an additional charge, this basic service can be extended with a user hotline [122]. 
The backend system also receives all relevant data (e.g., ID of the charging point being used, charging time, amount of electricity delivered, i.e., meter reading, ID of access medium) for billing [122].

Furthermore, the backend system forms the basis for a roaming platform. This platform allows for customers to use charging stations of different operators, meaning that all of the data must be exchanged via a roaming platform. This includes customer data, billing data as well as data of charging stations (e.g., geodata, plug type, charging capacity, and occupation status).

At the moment, there is no platform available to manage all customers, because operating such a roaming platform entails costs that are, at least for the time being, not justified by any corresponding demand. Another reason is that the technology is not yet mature. There are problems due to the divergent methods of access and payment, which lead to non-transparent pricing for customers.

\subsubsection{Authorization Process}

Before a charging station can be installed, various government agencies (e.g., department of transportation, urban development, and planning, building department, public order office, building supervisory authority, and public utility) must be consulted; no construction work can be done without their approval. The approval of such a construction measure takes a lot of time and is accordingly very complex. The approval process should take less than three months from mid-2020 onwards, according to the German Association of the Automotive Industry (VDA) [123]. This bureaucratic hurdle is a major factor in the slow expansion of the charging infrastructure.

\section{Development in the Social Acceptance of Electric Vehicles}

Social acceptance is indispensable to successfully establish electric mobility in the automotive market. At the moment, public opinion of the following aspects of electric vehicles is very critical (see Figure 5): high acquisition costs, security concerns, limited range, long charging time, and poorly developed charging infrastructure.

Figure 15 shows a graphical representation of development in the social acceptance of electric vehicles from 2011 and 2020 in Germany. The data are based on two different studies: a recent study [124] and a study from 2011 [125]. Both of the studies used surveys on the critical aspects mentioned above. In the more recent study, up to 1000 people were interviewed, and the study from 2011 interviewed around 700 people. The studies only represent the general opinion of the population on electric vehicles. Understandably, the data sets cannot otherwise be compared in principle.

Nevertheless, a fundamental change of view of electric vehicles is noticeable within nine years. In Figure 15, the orange line reflects the statements and sentiments from 2011 and runs well outside the blue line from 2020, meaning that people were much more skeptical and unwilling to invest and trust in new technology at that time. $100 \%$ means a high weighting (extraordinary importance) and $0 \%$ means no weighting (no importance at all). The strong deviation in the aspect of security is what is particularly striking here. $83 \%$ of participants have placed security directly behind the aspect of environmental friendliness. $87 \%$ of participants in 2011 were against electric vehicles, as they believed that electric vehicles are more environmentally harmful overall than conventional vehicles. Both of the views have changed fundamentally. Today, only $8 \%$ are concerned about security, and $38 \%$ think that electric vehicles are more environmentally harmful than conventional vehicles. For this reason, the aspect of environmental friendliness was also taken up in Figure 15, even though it is listed in Figure 5 under the benefits of electric mobility. Acquisition costs $(70 \%)$, range $(67 \%)$, charging time $(72 \%)$, and charging infrastructure $(62 \%)$ were also rated to be very problematic in 2011. This finding is also supported by the study [126]. Technological advancement, particularly in the area of batteries, has made it possible to achieve an improved acceptance. This acceptance, at least in part, comes from the fact that batteries have a major influence on vehicle prices (see Section 2.1), and that further 
distances can be covered (see Section 2.3) and by improving range prediction software (see Section 2.1). Furthermore, charging stations have also been further developed, so that electric vehicles can be charged with high charging capacities of $150 \mathrm{~kW}$ (DC) within a few minutes (depending on battery capacity) (see Sections 2.4 and 2.5). Accordingly, the survey results reveal that the acquisition costs and range were rated as $20 \%$ lower when compared to 2011, while the charging time was rated as much as 30\% lower. Perceptions of the charging infrastructure have also changed noticeably in those nine years, which can be explained by the government funding programs for expanding the charging infrastructure (see Section 2.5.1). Here, the challenge is to ensure that the charging infrastructure does not grow arbitrarily and unbalanced. Optimal distribution is a complex issue and it encompasses many influencing factors (see Section 2.5).

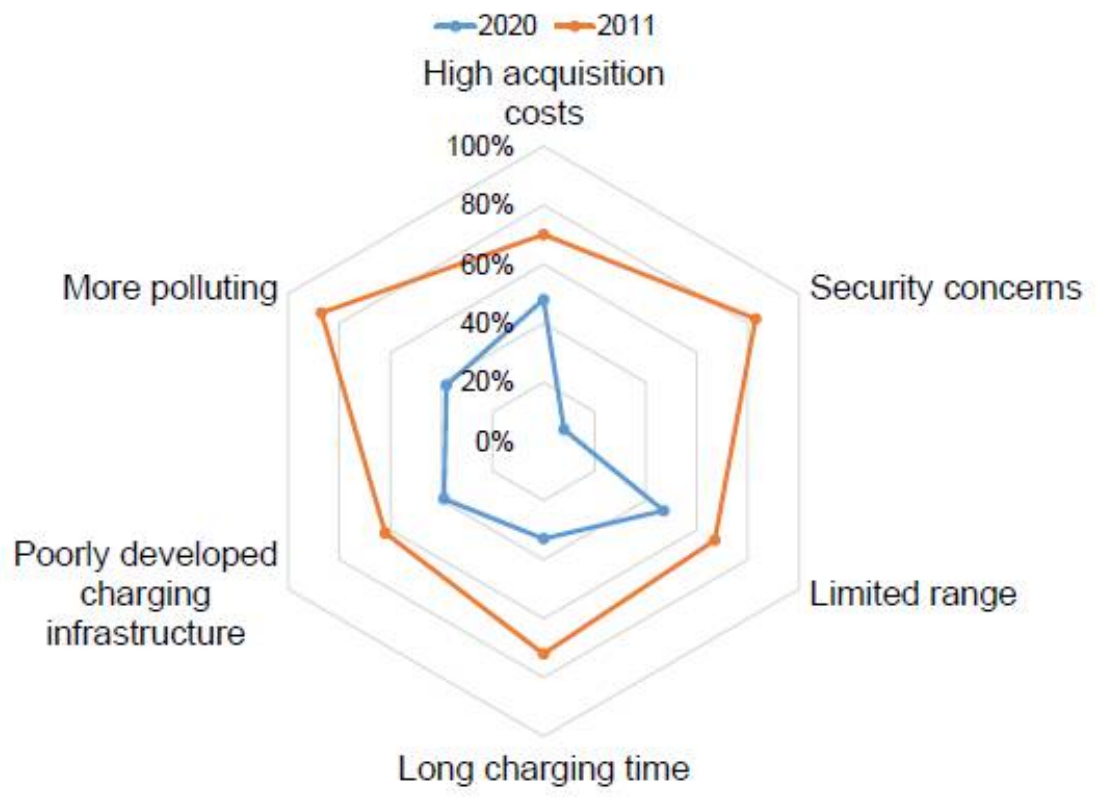

Figure 15. Comparison of social acceptance of electric vehicles in 2011 and 2020.

\section{Conclusions}

The successful establishment of electric mobility as a viable competitor to conventional mobility depends not only on technology, but also on social acceptance. In this work, the focus was mainly on barriers to the acceptance of electric mobility, whereby the range and charging infrastructure were explored in even more depth.

The battery is one of the key technologies for the driving range of electric mobility and, unfortunately, also a cost factor that makes EVs more expensive than conventional vehicles. The prices of battery pack have fallen by $75 \%$ since 2010 to around $\$ 200$, and they are expected to continue to fall (estimated to be $\$ 94$ by 2024 and $\$ 62$ by 2030). EVs on the market that cost about as much as a conventional vehicle tend to be the exception. However, with the price forecasts for battery packs, a positive price development of EVs can be expected within the next years.

Based on the results that were obtained in Section 2.3, it can be concluded that the range correlates with the price of EVs, leading to less range anxiety today for owners or potential buyers of luxury vehicle models (e.g., Audi e-tron Sportback 55). Additionally, vehicle technology is now much more advanced and, on average, EVs have a range of up to $400 \mathrm{~km}$, which is more than sufficient in everyday life according to statistics. The majority of those concerned about the driving range of EVs have no experience with electric vehicles. Nevertheless, range anxiety still exists, and it needs to be further investigated in future research. PHEVs are a promising solution for overcoming range anxiety. By driving PHEVs, potential buyers of EVs get into contact with vehicles that are powered by electrical energy. 
A growing experience with such vehicles can lead to a reduction of range anxiety, although further research is required before any definitive statements can be made in this regard.

Furthermore, the range is optimized by technological means. By knowing the current vehicle mass and determining its payload, energy consumption and the available driving range can be calculated by a process that is referred to as 'range prediction'. Another option is the range extender, which converts, e.g., the energy of a combustion engine (mechanical energy) into electrical energy while driving and, thus, increases the range.

The further focus of this study was on the complexity of planning a charging infrastructure for EVs. It was emphasized that planning is particularly influenced by the target group and the geographical characteristics of a region. Based on this, other factors must then be considered to 'fine-tune' the charging infrastructure planning; these may include the type of charging station, access, payment, pricing modalities, backend, and roaming.

The opinion on electric mobility has changed significantly between 2011 and 2020. This means that education, ongoing technology development, and the federal government's funding programs are effective and moving in the right direction. However, the aspects of range (2011: 67\%, 2020: 47\%), acquisition costs (2011: 70\%, 2020: 48\%), and the charging infrastructure (2011: 62\%, 2020: 39\%) are still critical points for many people. This paper seeks to answer the research question of whether the current measures are sufficient for having a positive effect on social acceptance. Accordingly, it can be stated that the measures taken so far have had a positive effect on social acceptance, but they must be further improved to have a sufficient number of EVs on the roads if emissions in the transport sector are to be reduced by $55 \%$ by 2030 , as envisaged by the EU. For example, consumer research would need new methods for determining the value of customer satisfaction with EV after purchase, i.e., how they communicate with peers about this satisfaction. Looking at the infrastructure in Germany, the most positive development is the support program "Climate Protection Program 2030", which primarily supports the expansion of the network of publicly accessible charging stations. On the other hand, it is also becoming increasingly important to promote the expansion of a private charging infrastructure, as around $65 \%$ of Germans indicated in a survey that they would prefer to charge at home. As of November 2020 , the German government has provided a subsidy of $€ 900$ against proof that a private charging station has been installed.

Introducing any new, not fully-developed technology for which no operative experiences are available is a challenge. On the one hand, customers do not want to buy into a technology that is not fully mature (e.g., battery capacity, range) and is relatively expensive, since not all of the potentials have been explored. On the other hand, the interest of operators to invest is low when there is no demand on the market for the product. This is a vicious cycle that impedes potentially beneficial technologies from reaching the level of prevalence that would unlock their potential for the benefit of all.

Author Contributions: Conceptualization, Visualization, Writing—original draft, review \& editing, A.B.; Writing—original draft, review \& editing, H.F.; Resources, Supervision, B.S. All authors have read and agreed to the published version of the manuscript.

Funding: This research received no external funding.

Conflicts of Interest: The authors declare no conflict of interest.

\section{References}

1. Kanellos, F.D.; Grigoroudis, E.; Hope, C.; Kouikoglou, V.S.; Phillis, Y.A. Optimal GHG Emission Abatement and Aggregate Economic Damages of Global Warming. IEEE Syst. J. 2014, 11, 2784-2793. [CrossRef]

2. European Environment Agency (EEA). Greenhouse Gas Emissions from Transport. Available online: https://www.eea.europa. $\mathrm{eu} /$ themes/transport (accessed on 26 August 2020).

3. Federal Ministry for the Environment. Nature Consenservation and Nuclear Safety. Klimawandel in Zahlen: Fakten, Trends und Impulse Deutscher Klimapolitik. Climate Action in Figures: Facts, Trends and Incentives for German Climate Policy. Available online: https:/ / www.bmu.de/fileadmin/Daten_BMU/Pools/Broschueren/klimaschutz_zahlen_2019_broschuere_ bf.pdf (accessed on 26 August 2020). 
4. Burkert, A.; Schmuelling, B. Challenges of Conceiving a Charging Infrastructure for Electric Vehicles-An Overview. In Proceedings of the 2019 IEEE Vehicle Power and Propulsion Conference (VPPC), Hanoi, Vietnam, 14-17 October 2019; pp. 1-5.

5. IRENA. Global Energy Transformation: A Roadmap to 2050. Internation Renewable Energy Agency. Available online: https:/ / www.irena.org/publications/2019/Apr/Global-energy-transformation-A-roadmap-to-2050-2019Edition (accessed on 26 August 2020).

6. Federal Motor Transport Authority. Pkw-Bestand in Deutschland nach Kraftstoffarten. Car Population in Germany by Fuel Type. Available online: https:/ / www.kba.de/DE/Statistik/Fahrzeuge/Bestand/bestand_node.html (accessed on 17 August 2020).

7. Wolfram, P.; Lutsey, N. Electric Vehicles: Literature Review of Technology Costs and Carbon Emissions; The International Council on Clean Transportation: Washington, DC, USA, 2016.

8. Nissan. Nissan Vehicles: Juke, Leaf and Micra. Available online: https:/ / www.nissan.de/ (accessed on 17 August 2020).

9. Lajunen, A. Evaluation of energy consumption and carbon dioxide emissions for electric vehicles in Nordic climate conditions. In Proceedings of the 2018 Thirteenth International Conference on Ecological Vehicles and Renewable Energies (EVER), Monte Carlo, Monaco, 10-12 April 2018; pp. 1-7.

10. VuMA. Autofahrer in Deutschland nach Selbstgefahrenen Kilometern pro Jahr von 2015 bis 2019 Drivers in Germany by Self-Driving Kilometres Per Year from 2015 to 2019; VuMA: Hamburg, Germany, 2020.

11. Hein, P.; Peter, F.; Graichen, P. Die Energiewende im Stromsektor: Stand der Dinge 2019. Energy Transition in Electricity Sector: Status in 2019. AGORA Energiewende. Available online: https://www.agora-energiewende.de/fileadmin2/Projekte/2019 /Jahresauswertung_2019/171_A-EW_Jahresauswertung_2019_WEB.pdf (accessed on 26 August 2020).

12. The International Council on Clean Transportation. European Electric Vehicle Factbook 2019/2020. Available online: https:/ / theicct.org/sites/default/files/publications/EV-EU-Factbook-2020.pdf (accessed on 2 December 2020).

13. Federal Motor Transport Authority. Durchschnittliche $\mathrm{CO}_{2}$-Emissionen der neu Zugelassenen Pkw in Deutschland von 1998 bis 2019. Average $\mathrm{CO}_{2}$ Emissions of Newly Registered Passenger Cars in Germany from 1998 to 2019. Available online: https:/ / www.kba.de/DE/Statistik/Fahrzeuge/Neuzulassungen/Umwelt/n_umwelt_inhalt.html (accessed on 17 August 2020).

14. Federal Motor Transport Authority. Neuzulassungsbarometer 2019 New Vehicle Registration Barometer 2017, $2018,2019$. Available online: https://wwwkbade/DE/Statistik/Fahrzeuge/Neuzulassungen/neuzulassungen_nodehtml (accessed on 17 August 2020).

15. EU631/2019. $\mathrm{CO}_{2}$ Emission Performance Standards for New Passenger Cars and for New Light Commercial Vehicles, and Repealing Regulations (EC); European Parliament: Brussels, Belgium, 2019.

16. Uthirakumar, A.; Manickam, I. Barriers of growth analysis for Electric Vehicles by non-linear polarized scale method. In Proceedings of the 2020 IEEE Transportation Electrification Conference \& Expo (ITEC), Chicago, IL, USA, 23-26 June 2020; pp. 14-16. [CrossRef]

17. Ziefle, M.; Beul-Leusmann, S.; Kasugai, K.; Schwalm, M. Public Perception and Acceptance of Electric Vehicles: Exploring Users' Perceived Benefits and Drawbacks. In Proceedings of the Mining Data for Financial Applications; Springer: Cham, Switzerland, 2014; pp. 628-639.

18. Adhikari, M.; Ghimire, L.P.; Kim, Y.; Aryal, P.; Khadka, S.B. Identification and Analysis of Barriers against Electric Vehicle Use. Sustainability 2020, 12, 4850. [CrossRef]

19. Statharas, S.; Moysoglou, Y.; Siskos, P.; Zazias, G.; Capros, P. Factors Influencing Electric Vehicle Penetration in the EU by 2030: A Model-Based Policy Assessment. Energies 2019, 12, 2739. [CrossRef]

20. Hosseinpour, S.; Chen, H.; Tang, H. Barriers to the wide adoption of electric vehicles: A literature review based discussion. In Proceedings of the 2015 Portland International Conference on Management of Engineering and Technology (PICMET), Portland, OR, USA, 2-6 August 2015; pp. 2329-2336. [CrossRef]

21. Un-Noor, F.; Padmanaban, S.; Mihet-Popa, L.; Mollah, M.N.; Hossain, E. A Comprehensive Study of Key Electric Vehicle (EV) Components, Technologies, Challenges, Impacts, and Future Direction of Development. Energies 2017, 10, 1217. [CrossRef]

22. Kroher, T. Kostenvergleich Elektro, Benzin oder Diesel: Lohnt es sich Umzusteigen? Cost Comparison of Electric, Petrol or Diesel: Is It Worth Changing? ADAC: Munich, Bavaria, 2020.

23. Tsiropoulos, T.; Tarvydas, D.; Lebedeva, N. Li-Ion Batteries for Mobility and Stationary Storage Applications: Scenarios for Costs and Market Growth; European Union: Brussels, Belgium, 2018.

24. Mathis, W. Cheaper Batteries, More Chargers for Electric Car Buyers in 2020. Available online: https://www.bloomberg.com/ news/articles/2020-01-13/cheaper-batteries-more-chargers-for-electric-car-buyers-in-2020 (accessed on 30 November 2020).

25. Zuccari, F.; Orecchini, F.; Santiangeli, A.; Suppa, T.; Ortenzi, F.; Genovese, A.; Pede, G. Well to wheel analysis and comparison between conventional, hybrid and electric powertrain in real conditions of use. In Proceedings of the Second International Conference on Material Science, Smart Structures and Applications: ICMSS-2019; AIP Publishing LLC.: Melville, NY, USA, 2019; Volume 2191, p. 020158.

26. Lou, P.; Xu, G.-H.; Yue, L.-P.; Cao, Y.-C.; Cheng, S.; Deng, H. Current Fire Safety challenges on Lithium Ion Battery for Grid Power Storage System. In Proceedings of the 2019 4th International Conference on Power and Renewable Energy (ICPRE), Chengdu, China, 21-23 September 2019; pp. 300-304.

27. Finegan, D.P.; Darcy, E.; Keyser, M.; Tjaden, B.; Heenan, T.M.M.; Jervis, R.; Bailey, J.J.; Malik, R.; Vo, N.T.; Magdysyuk, O.V.; et al. Characterising thermal runaway within lithium-ion cells by inducing and monitoring internal short circuits. Energy Environ. Sci. 2017, 10, 1377-1388. [CrossRef] 
28. Kulkarni, M.; Sundaram, S.M.; Diwakar, V. Development of sensor and optimal placement for smoke detection in an electric vehicle battery pack. In Proceedings of the 2015 IEEE International Transportation Electrification Conference (ITEC), Chennai, India, 27-29 August 2015; pp. 1-3.

29. Sun, P.; Biscchop, R.; Niu, H.; Huang, X. A review of battery fires in electric vehicles. Fire Technol. 2020, 1-5. [CrossRef]

30. Deloitte. New Market. New Entrants. New Challenges. Battery Electric Vehicles. Available online: https://www2.deloitte.com/ content/dam/Deloitte/uk/Documents/manufacturing/deloitte-uk-battery-electric-vehicles.pdf (accessed on 26 August 2020).

31. AAA Foundation for Traffic Safety. American Driving Survey, 2015-2016. Available online: https://aaafoundation.org/wpcontent/uploads/2018/01/19-0226_AAAFTS-2018-ADAS-Research-Brief-Update_v1.pdf (accessed on 26 August 2020).

32. Nobis, C.; Kuhnimhof, T. Mobilität in Deutschland-MID Ergebnisbericht Mobility in Germany-MID Results Report. Available online: http:/ / www.mobilitaet-in-deutschland.de/pdf/MiD2017_Ergebnisbericht.pdf (accessed on 26 August 2020).

33. International Energy Agency. Global EV Outlook 2019: Scaling-Up the Transition to Electric Mobility. Available online: https: / / www.oecd-ilibrary.org / docserver /35fb60bd-en.pdf? expires=1612944671\&id=id\&accname=ocid177160\&checksum=83 A0529C89705E916AFEEDA74DBAA39A (accessed on 26 August 2020).

34. European Alternative Fuels Observatory. Market Share New Registrations. December 2020. Available online: https://www.eafo. $\mathrm{eu} /$ vehicles-and-fleet/m1 (accessed on 15 January 2021).

35. Association des Constructeurs Européens d'Automobiles. Passenger Car Registrations: - 25.5\% 11 Months into 2020; $12.0 \%$ in November. 17 December 2020. Available online: https:/ / www.acea.be/press-releases/article/passenger-car-registrations-25.5-1 1-months-into-2020-12.0-in-november (accessed on 15 January 2021).

36. Federal Motor Transport Authority. Vehicle Registration in December 2020—Annual Report—Fahrzeugzulassungen im Dezember 2020-Jahresbilanz. 31 December 2020. Available online: https://www.kba.de/SharedDocs/Pressemitteilungen/DE/2021/pm_ 02_2021_fahrzeugzulassungen_12_2020_pdf (accessed on 15 January 2021).

37. Cleantechnica. Record Electric Vehicle Sales in Europe. 29 December 2020. Available online: https://cleantechnica.com/2020/1 2/29/record-electric-vehicle-sales-in-europe/ (accessed on 15 January 2021).

38. Bloch, C.; Newcomb, J.; Shiledar, S.; Tyson, M. Breakthrough Batteries-Power the Era of Clean Electrification. Available online: https://rmi.org/wp-content/uploads/2019/10/rmi_breakthrough_batteries.pdf (accessed on 2 December 2020).

39. De Cauwer, C.; Van Mierlo, J.; Coosemans, T. Energy Consumption Prediction for Electric Vehicles Based on Real-World Data. Energies 2015, 8, 8573-8593. [CrossRef]

40. International Energy Agency. Global EV Outlook 2018. Available online: https://www.iea.org/reports/global-ev-outlook-2018 (accessed on 26 August 2020).

41. Küpper, D.; Kuhlmann, K.; Wolf, S.; Pieper, C.; Xu, G.; Ahmad, J. The Future of Battery Production for Electric Vehicles. Available online: https:/ / www.bcg.com/de-de/publications/2018/future-battery-production-electric-vehicles (accessed on 26 August 2020).

42. Zubi, G.; Dufo-López, R.; Carvalho, M.; Pasaoglu, G. The lithium-ion battery: State of the art and future perspectives. Renew. Sustain. Energy Rev. 2018, 89, 292-308. [CrossRef]

43. Berckmans, G.; Messagie, M.; Smekens, J.; Omar, N.; Vanhaverbeke, L.; Van Mierlo, J. Cost Projection of State of the Art Lithium-Ion Batteries for Electric Vehicles Up to 2030. Energies 2017, 10, 1314. [CrossRef]

44. Baes, K.; Kolk, M.; Merhaba, A.; Carlot, F.; Ito, Y. Future of Batteries: Winner Takes All? Available online: https:/ /www.adlittle. $\mathrm{com} /$ sites/default/files/viewpoints/adl_future_of_batteries-min.pdf (accessed on 26 August 2020).

45. European Commission. Future Brief: Towards the Battery of the Future. Available online: https://ec.europa.eu/environment/ integration/research/newsalert/pdf/towards_the_battery_of_the_future_FB20_en.pdf (accessed on 26 August 2020).

46. Frith, J. Lithium-Ion Batteries: The Incumbent Technology. Available online: https://ec.europa.eu/energy/sites/ener/files/ documents /6.1_frith_energy_storage.pdf (accessed on 26 August 2020).

47. Barcellona, S.; De Simone, D.; Piegari, L. Control strategy to improve EV range by exploiting hybrid storage units. IET Electr. Syst. Transp. 2019, 9, 237-243. [CrossRef]

48. Sautermeister, S.; Thorgeirsson, A.T.; Vaillant, M.; Gauterin, F. A Stochastic Range Estimation Algorithm for Electric Vehicles Using Traffic Phase Classification. IEEE Trans. Veh. Technol. 2019, 68, 6414-6428. [CrossRef]

49. Tomaszewska, A.; Chu, Z.; Feng, X.; O’Kane, S.; Liu, X.; Chen, J.; Ji, C.; Endler, E.; Li, R.; Liu, L.; et al. Lithium-ion battery fast charging: A review. eTransportation 2019, 1. [CrossRef]

50. Nilsson, M. Electric Vehicle: The Phenomenon of Range Anxiety. Available online: http://e-mobility-nsr.eu/fileadmin/user_ upload/downloads/info-pool/the_phenomenon_of_range_anxiety_elvire.pdf (accessed on 26 August 2020).

51. Mitsubishi Motors. 2012 Mitsubishi i-MiEV Product Brief. Available online: http://manitobaev.ca/wp-content/uploads/2011/1 1/i-Miev-product-brief.pdf (accessed on 26 August 2020).

52. Pevec, D.; Babic, J.; Carvalho, A.; Ghiassi-Farrokhfal, Y.; Ketter, W.; Podobnik, V. Electric Vehicle Range Anxiety: An Obstacle for the Personal Transportation (R)evolution? In Proceedings of the 2019 4th International Conference on Smart and Sustainable Technologies (SpliTech), Split, Croatiab, 18-21 June 2019.

53. Faraj, M.; Fidan, B.; Gaudet, V. Multi-Module Range Anxiety Reduction Scheme for Battery-Powered Vehicles. 2018 IEEE Intell. Veh. Symp. (IV) 2018, 904-909. [CrossRef]

54. Franke, T. Nachhaltige Mobilität mit Begrenzten Ressourcen: Erleben und Verhalten im Umgang mit der Reichweite von Elektrofahrzeugen; TU Chemnitz: Qucosa, Saxony, 2013. 
55. Sautermeister, S.; Falk, M.; Baker, B.; Gauterin, F.; Vaillant, M. Influence of Measurement and Prediction Uncertainties on Range Estimation for Electric Vehicles. IEEE Trans. Intell. Transp. Syst. 2018, 19, 2615-2626. [CrossRef]

56. Rauh, N.; Franke, T.; Krems, J.F. Understanding the Impact of Electric Vehicle Driving Experience on Range Anxiety. Hum. Factors J. Hum. Factors Ergon. Soc. 2014, 57, 177-187. [CrossRef]

57. Fechtner, H.; Teschner, T.; Schmuelling, B.; Heiko, F. Range prediction for electric vehicles: Real-time payload detection by tire pressure monitoring. 2015 IEEE Intell. Veh. Symp. (IV) 2015, 767-772. [CrossRef]

58. Fechtner, H. Fahrzeugmasseüberwachung Mittels Intelligentem Reifendruckkontrollsystem im Kontext der Reichweitenproblematik von Elektrofahrzeugen; University of Wuppertal: Wuppertal, Germany; Shaker Verlag: Aachen, Germany, 2019.

59. Clarke, I.; Athena, P. Range extenders: An innovative approach to range anxiety in electric vehicles. Int. J. Automot. Technol. Manag. 2019, 19, 104-124. [CrossRef]

60. Fukushima, A.; Yano, T.; Imahara, S.; Aisu, H.; Shimokawa, Y.; Shibata, Y. Prediction of energy consumption for new electric vehicle models by machine learning. IET Intell. Transp. Syst. 2018, 12, 1174-1180. [CrossRef]

61. Varga, B.O.; Sagoian, A.; Mariasiu, F. Prediction of Electric Vehicle Range: A Comprehensive Review of Current Issues and Challenges. Energies 2019, 12, 946. [CrossRef]

62. Knutsen, D.; Willén, O. A Study of Electric Vehicle Charging Patterns and Range Anxiety; Uppsala University: Uppsala, Sweden, 2013.

63. Apostolaki-Iosifidou, E.; Codani, P.; Kempton, W. Measurement of power loss during electric vehicle charging and discharging. Energy 2017, 127, 730-742. [CrossRef]

64. Mussa, A.S.; Liivat, A.; Marzano, F.; Klett, M.; Philippe, B.; Tengstedt, C.; Lindbergh, G.; Adström, K.; Lindström, R.W.; Svens, P. Fast-charging effects on ageing for energy-optimized automotive LiNi1/3Mn1/3Co1/3O2/graphite prismatic lithium-ion cells. J. Power Sources 2019, 175-184. [CrossRef]

65. Porsche. The New Taycan 4S-Press Kit. Available online: https://newsroom.porsche.com/de/produkte/taycan.html (accessed on 17 August 2020).

66. Speers, P. Hydrogen Mobility Europe (H2ME): Vehicle and Hydrogen Refuelling Station Deployment Results. World Electr. Veh. J. 2018, 9, 2. [CrossRef]

67. Chen, X.C.X.; Jiang, T.J.T.; Bi, M.B.M.; Wang, Y.W.Y.; Gao, H.G.H. A review of condition assessment of charging infrastructure for electrical vehicles. In Proceedings of the IET International Conference on Intelligent and Connected Vehicles (ICV 2016), Chongqing, China, 22-23 September 2016.

68. Hirsch, H.; Jeschke, S.; Wei, L.; Trautmann, M.; Barenfanger, J.; Maarleveld, M.; Heyen, J.; Darrat, A. Latest development of the national and international EMC-standards for electric vehicles and their charging infrastructure. In Proceedings of the 2015 IEEE International Symposium on Electromagnetic Compatibility (EMC), Dresden, Germany, 16-22 August 2015; pp. 708-713.

69. House, M.; Wright, D. Funding an electric vehicle charging infrastructure from associated health benefits. In Proceedings of the 2016 IEEE Electrical Power and Energy Conference (EPEC), Ottawa, ON, Canada, 12-14 October 2016; pp. 1-5.

70. Ma, T.; Mohammed, O.A. Optimal charging of plug-in electric vehicles for a car-park infrastructure. IEEE Trans. Ind. Appl. 2014, Volume 50, 2323-2330.

71. Ferguson, B.; Nagaraj, V.; Kara, E.C.; Alizadeh, M. Optimal Planning of Workplace Electric Vehicle Charging Infrastructure with Smart Charging Opportunities. In Proceedings of the 2018 21st International Conference on Intelligent Transportation Systems (ITSC), Maui, HI, USA, 4-7 November 2018; pp. 1149-1154.

72. Porru, M.; Serpi, A.; Mureddu, M.; Damiano, A. A Combined Planning and Design Approach of a Public Charging Infrastructure for Electric Vehicles. In Proceedings of the 2018 IEEE Vehicle Power and Propulsion Conference (VPPC), Chicago, IL, USA, 27-30 August 2018; pp. 1-5.

73. Van Montfort, K.; Van Der Poel, G.; Visser, J.; Hoed, R.V.D. Prediction of necessary public charging infrastructure of electric vehicles. In Proceedings of the 6th Hybrid and Electric Vehicles Conference (HEVC 2016), London, UK, 2-3 November 2016.

74. Schuler, D.; Gabba, G.; Küng, L.; Peter, V. How a city prepares to e-mobility in terms of public charging infrastructure case study the city of Zurich. 2013 World Electr. Veh. Symp. Exhib. (EVS27) 2013, EVS27, 1-7. [CrossRef]

75. Yilmaz, M.; Krein, P.T. Review of charging power levels and infrastructure for plug-in electric and hybrid vehicles. In Proceedings of the 2012 IEEE International Electric Vehicle Conference, Greenville, SC, USA, 7 March 2012; pp. 1-8. [CrossRef]

76. Auf der Maur, A.; Brueggeshemke, N.; Kutschera, M. Development of the Publicly Accessible Charging Infrastructure for Electric Mobility and Comparison of Charging Rates in Germany; EnBW: Karlsruhe, Germany, 2020.

77. 2014/94/EU. On the Deployment of Alternative Fuels Infrastructure: 2014/94/EU; European Parliament: Brussels, Belgium, 2014.

78. Federal Ministry of Transport and Digital Infrastructure. Förderrichtlinie Ladeinfrastruktur für Elektrofahrzeuge in Deutschland Funding Guideline for Charging Infrastructure for Electric Vehicles in Germany; BMVI: Berlin, Germany, 2017.

79. German Federal Government. Masterplan Ladeinfrastruktur der Bundesregierung-Ziele und Maßnahmen für den LADEINFRASTRUKTURAUFBAU bis 2030 Master Plan for Charging Infrastructure of Federal Government-Aims and Measures for Design Configuration of Charging Infrastructure until 2030; BReg: Berlin, Germany, 2019.

80. Wolter, A. Zahl der Woche: 65 Prozent der Deutschen Würden ihr E-Auto vor Allem Zuhause Laden Number ot the Week: 65 Percent of Germans Would Charge Their Electric Vehicle at Home. Available online: https://www.bdew.de/energie/ elektromobilitaet-dossier/private-ladeinfrastruktur-foerdern/ (accessed on 26 August 2020). 
81. NOW GmbH. 900 euros for Private Charging Stations: List of Models Eligible for Funding Published. NOW. Available online: www.now-gmbh.de/en/news/pressreleases/900-euros-for-private-charging-stations-list-of-models-eligible-for-fundingpublished/ (accessed on 30 November 2020).

82. EERE. Electric Vehicle Charging Station Locations. Available online: https://afdc.energy.gov/fuels/electricity_locations.html\# /find/nearest?fuel=ELEC\&ev_levels=all (accessed on 26 August 2020).

83. Nicholas, M.; Hall, D.; Lutsey, N. Quantifying the Electric Vehicle Charging Infrastructure Gap across U.S. Markets. Available online: https: / / theicct.org/publications/ charging-gap-US (accessed on 26 August 2020).

84. Wood, E.W.; Rames, C.L.; Bedir, A.; Crisostomo, N.; Allen, J. California Plug-in Electric Vehicle Infrastructure Projections: 2017-2025Future Infrastructure Needs for Reaching the State's Zero Emission-Vehicle Deployment Goals; National Renewable Energy Lab.(NREL): Golden, CO, USA, 2018.

85. Todts, W. European Federation for Transport and Environment AISBL. Available online: https: / / www.transportenvironment. org/sites/te/files/publications / 11\%202020\%20Draft\%20TE\%20Infrastructure\%20Report\%20Final.pdf (accessed on 26 August 2020).

86. Statistics Norway. Number of Registered Vehicles in Norway in 2019, by Type, SSB. Available online: www.ssb.no/en/statbank/ table/01960/?rxid=dc650bf9-dd86-49ea-bc7c-bbabecdda1b9 (accessed on 27 November 2020).

87. Norsk Elbilforening. Norwegian EV Market, elbil. Available online: www.elbil.no/english/norwegian-ev-market/ (accessed on 27 November 2020).

88. European Alternative Fuels Observatory. EAFO: The Netherlands. Available online: www.eafo.eu/countries/netherlands/1746 / summary (accessed on 27 November 2020).

89. Holteng, P.; te Riele, D. E-Mobility in Norway, Opportunity Report by the Embassy of the Kingdom of the Netherlands in Norway; Embassy of the Kingdom of the Netherlands in Norway: Norway, The Netherlands, 2019.

90. RVO. Statistics Electric Vehicles in the Netherlands; Netherlands Enterprise Agency: The Hague, The Netherlands; Available online: https: / www.rvo.nl/sites / default/files / 2020/08/Statistics\%20Electric\%20Vehicles\%20and\%20Charging $\% 20 \mathrm{in} \% 20$ The $\%$ 20Netherlands\%20up\%20to\%20and\%20including\%20July\%202020.pdf (accessed on 10 February 2021).

91. German Federal Motor Transport Authority. Annual Balance Sheet of the Vehicle Stock on January 2019. Available online: www.kba.de/DE/Statistik/Fahrzeuge/Bestand/b_jahresbilanz (accessed on 27 November 2020).

92. NRDC. Scaling Up Electric Vehicles Charging Infrastructure: Lessons from China and the United States for the Indian Context; Natural Resources Defense Council: New York, NY, USA, 2020.

93. Straka, M.; De Falco, P.; Ferruzzi, G.; Proto, D.; Van Der Poel, G.; Khormali, S.; Buzna, L. Predicting Popularity of Electric Vehicle Charging Infrastructure in Urban Context. IEEE Access 2020, 8, 11315-11327. [CrossRef]

94. Zhang, Y.; Zhao, H.; Li, H. The study on city general planning and management information system based on GIS. In Proceedings of the 2010 International Conference on Computer Application and System Modeling (ICCASM 2010), Taiyuan, China, 22-24 October 2010.

95. Bonan, M.; Daenner, S.; Mayer, C.; Warnecke, T. Approval Process of Charging Infrastructure in Municipalities: Strategic and Legal Issues; Federal Ministry of Transport and Digital Infrastructure: Berlin, Germany, 2014.

96. Gehrlein, T.; Schultes, B. Praxishandbuch Ladesäulen-Infrastruktur, Handbook Charging Station Infrastructure; Thorsten Gehrlein: Bonn, Germany, 2017.

97. Dai, Y.; Liu, M. An electricity demand-based planning of electric vehicle charging infrastructure. Wuhan Univ. J. Nat. Sci. 2017, 22, 449-454. [CrossRef]

98. Ibrahim, H.E.-D. Car Parking Problem in Urban Areas, Causes and Solutions. SSRN Electron. J. 2017. [CrossRef]

99. NPE. Die Deutsche Normungs-Roadmap Elektromobilität 2020: 7AG) 4-Normung, Standardisierung und Zertifizierung German Standardization Roadmap Electric Mobility 2020: 7AG 4-Standardization and Certification; Nationale Plattform Elektromobilität: Berlin, Germany, 2020.

100. Habib, S.; Khan, M.M.; Hashmi, K.; Ali, M.; Tang, H. A Comparative Study of Electric Vehicles Concerning Charging Infrastructure and Power Levels. In Proceedings of the 2017 International Conference on Frontiers of Information Technology (FIT), Islamabad, Pakistan, 18-20 December 2017; pp. 327-332.

101. Hutchinson, L.; Waterson, B.; Anvari, B.; Naberezhnykh, D. Potential of wireless power transfer for dynamic charging of electric vehicles. IET Intell. Transp. Syst. 2019, 13, 3-12. [CrossRef]

102. IEC61851-3. Electric Vehicle Conductive Charging System; IEC: Geneva, Switzerland, 2017.

103. IEC62196. Plugs, Socket-Outlets, Vehicle Connectors and Vehicle Inlets-Conductive Charging of Electric Vehicles; IEC: Geneva, Switzerland, 2014.

104. ISO15118. Road Vehicles_Vehicle to Grid Communication Interface; ISO: Geneva, Switzerland, 2019.

105. IEC62752. In-Cable Control and Protection Device for Mode 2 Charging of Electric Road Vehicles (IC-CPD); IEC: Geneva, Switzerland, 2016.

106. IEC62893. Charging Cables for Electric Vehicles for Rated Voltages up to and Including 0.6/1 kV; IEC: Geneva, Switzerland, 2017.

107. ISO17409. Electrically Propelled Road Vehicles_Conductive Power Transfer-Safety Requirement; ISO: Geneva, Switzerland, 2020.

108. IEC60364-7-722. Low-Voltage Electrical Installations_Part 7-722: Requirements for Special Installations or Locations-Supplies for Electric Vehicles; ISO: Geneva, Switzerland, 2018. 
109. Gao, Y.; Farley, K.B.; Tse, Z.T.H. Investigating safety issues related to Electric Vehicle wireless charging technology. In Proceedings of the 2014 IEEE Transportation Electrification Conference and Expo (ITEC), Dearborn, MI, USA, 15-18 June 2014; pp. 1-4.

110. Kluth, R.; Ziegner, J. Inductive charging-Simplifying the charge to enable mass adoption. World Electr. Veh. J. 2012, 5, 714-721. [CrossRef]

111. MAGMENT. 2020. Available online: https:/ /www.magment.de/en-dynamic-wireless-charging (accessed on 13 January 2021).

112. European Green Vehicles Initiative. February 2014. Available online: https:/ / egvi.eu/project-highlight/unplugged-inductivecharging-for-electric-vehicles-february-2014/ (accessed on 13 January 2021).

113. ISO19363. Electrically Propelled Road Vehicles-Magnetic Field Wireless Power Transfer-Safety and Interoperability Requirements; ISO: Geneva, Switzerland, 2020.

114. IEC61980. Electric Vehicle Wireless Power Transfer (WPT) Systems; IEC: Geneva, Switzerland, 2015.

115. CISPR11. Industrial Scientific and Medical Equipment_Radio-Frequency Disturbance Characteristics_Limits and Methods of Measurement; CISPR: Ispra, Italy, 2019.

116. IEC62764. Measurement Procedures of Magnetic Field Levels Generated by Electronic and Electrical Equipment in the Automotive Environment with Respect to Human Exposure; IEC: Geneva, Switzerland, 2019.

117. BMW Group. Charging even Easier than Refuelling. BMW. Available online: www.press.bmwgroup.com/deutschland/article/ detail/T0281369DE/laden-noch-einfacher-als-tanken?language=de (accessed on 1 December 2020).

118. Kvisle, H.H.; Myklebust, B.A. Development of Charging Station Data Services for New User Groups. 2013 World Electric Vehicle Symposium and Exhibition (EVS27) 2013, EVS27, 1-6. [CrossRef]

119. Hollenbach, M. Bautzen Soon Parks without Change. Available online: www.saechsische.de/plus/bautzen-parkt-bald-ohnekleingeld-5035673.html (accessed on 30 November 2020).

120. Playfair Parking. What Does A Parking Ticket Machine Cost? Available online: www.playfair-parking.de/blog/was-kostet-einparkscheinautomat/ (accessed on 30 November 2020).

121. Divyapriya, S.; Amutha; Vijayakumar, R. Design of Residential Plug-in Electric Vehicle Charging Station with Time of Use Tariff and IoT Technology. In Proceedings of the 2018 International Conference on Soft-computing and Network Security (ICSNS), Coimbatore, India, 14-16 February 2018; pp. 1-5.

122. Gagnol, P.; Jochem, P.; Pierre, M.; Fichtner, W. CROME: The French and German field demonstration of the interoperable mobility with EVs. 2013 World Electr. Veh. Symp. Exhib. (EVS27) 2013, EVS27, 1-8. [CrossRef]

123. German Associtation of the Automotive Industry. Position-Recommendations for a Successful Ramp-up of the Charging Infrastructure for Electric Vehicles by 2030. VDA. Available online: www.vda.de/de/services/Publikationen/positionspapierladeinfrastruktur (accessed on 27 November 2020).

124. Buehler, J.; Goebelt, R.; Shahd, M. Mobility Study 2020; Technical Inspection Association: Stuttgart, Germany, 2020.

125. Globisch, J.; Schneider, U.; Duetschke, E. Acceptance of electric vehicles by commercial users in the electric mobility pilot regions in Germany. In ECEEE Summer Study Proceedings; ECEEE: Stockholm, Sweden, 2013; pp. 973-983.

126. Cocron, P.; Bühler, F.; Neumann, I.; Franke, T.; Krems, J.F.; Schwalm, M.; Keinath, A. Methods of Evaluating Electric Vehicles from a User's Perspective-The MINI E Field Trial in Berlin. IET Intell. Transp. Syst. 2011, 5, 127-133. [CrossRef] 